\title{
The influence of delivery vectors on HIV vaccine efficacy
}

\section{Beatrice O. Ondondo*}

Nuffield Department of Medicine, The Jenner Institute, University of Oxford, Oxford, UK

Edited by:

Shuo Li, The University of

Melbourne, Australia

Reviewed by:

Andrew Lucas, Murdoch University,

Australia

Cody Charles Allison, Walter and

Eliza Hall Institute, Australia

*Correspondence:

Beatrice O. Ondondo, Nuffield Department of Medicine, The Jenner Institute, University of Oxford, ORCRB, Roosevelt Drive,

Oxford, OX3 7DQ, UK

e-mail: beatrice.ondondo@

ndm.ox.ac.uk
Development of an effective HIV/AIDS vaccine remains a big challenge, largely due to the enormous HIV diversity which propels immune escape. Thus novel vaccine strategies are targeting multiple variants of conserved antibody and $T$ cell epitopic regions which would incur a huge fitness cost to the virus in the event of mutational escape. Besides immunogen design, the delivery modality is critical for vaccine potency and efficacy, and should be carefully selected in order to not only maximize transgene expression, but to also enhance the immuno-stimulatory potential to activate innate and adaptive immune systems. To date, five HIV vaccine candidates have been evaluated for efficacy and protection from acquisition was only achieved in a small proportion of vaccinees in the RV144 study which used a canarypox vector for delivery. Conversely, in the STEP study (HVTN 502) where human adenovirus serotype 5 (Ad5) was used, strong immune responses were induced but vaccination was more associated with increased risk of HIV acquisition than protection in vaccinees with pre-existing Ad5 immunity. The possibility that pre-existing immunity to a highly promising delivery vector may alter the natural course of HIV to increase acquisition risk is quite worrisome and a huge setback for HIV vaccine development. Thus, HIV vaccine development efforts are now geared toward delivery platforms which attain superior immunogenicity while concurrently limiting potential catastrophic effects likely to arise from pre-existing immunity or vector-related immuno-modulation. However, it still remains unclear whether it is poor immunogenicity of HIV antigens or substandard immunological potency of the safer delivery vectors that has limited the success of HIV vaccines. This article discusses some of the promising delivery vectors to be harnessed for improved HIV vaccine efficacy.

Keywords: HIV-1, vaccines, delivery vectors, MVA, NYVAC, adenovirus, ALVAC, DNA

\section{INTRODUCTION}

Thirty years after the discovery of HIV/AIDS, the search for a safe and effective vaccine has intensified, as a number of promising candidate vaccines progressing to phase IIb/III clinical trials have failed to show efficacy. One of the greatest barriers to HIV vaccine development is the enormous virion diversity (depicted by the existence of numerous clades and subtypes in distinct geographic demarcations) and the continuous evolution which generates numerous quasi-species within an infected individual (Hemelaar et al., 2011). This not only makes it challenging to create immunogens which are effectively matched to the circulating target viruses, but also provides room for immune escape of HIV from potent vaccine-induced immune responses. Therefore, it has emerged that immunogens derived from the most conserved regions of HIV and covering multiple variants (conserved mosaics) stand out as the most suitable candidates for T-cell based vaccines, while immunogens covering the most potent and broadly neutralizing and non-neutralizing antibody epitopes are better for antibody-based vaccines (Emini and Koff, 2004; Robinson and Amara, 2005; McMichael, 2006; Letourneau et al., 2007; Thorner and Barouch, 2007; Sekaly, 2008; Korber et al., 2009; Barouch et al., 2010; Santra et al., 2010; Borthwick et al., 2014). However, the development of a vaccine based on conserved antibody epitopes to provide protective global coverage and to minimize immune escape is hampered by inaccessibility of the highly shielded conserved envelope domains. Furthermore, the observation that development of broadly neutralizing antibodies requires prolonged stimulation with higher antigenic loads from divergent virus species (van Gils and Sanders, 2013) implies that HIV vaccine strategies must provide a continuous high level expression of a cocktail of immunogens. Although the use of polyvalent T-cell and B-cell mosaic constructs or the conserved consensus sequences may effectively overcome the challenges of HIV diversity and significantly improve vaccine efficacy (Santra et al., 2010, 2012), the lack of clearly defined correlates of efficacy means that it remains unclear what immune responses an HIV vaccine should aim to induce. Recently, a non-human primate (NHP) study based on the RhCMV vector induced exceptionally broad and persistent atypical CD8 $+\mathrm{T}$ cells which effectively cleared SIV and maintained durable suppression of virus replication (Hansen et al., 2009, 2011, 2013), suggesting that HIV vaccine development research may have to adapt immunogen design and delivery strategies that stimulate similar responses.

Delivery vectors are vital and integral components of a successful vaccine as they play an important role in modulating both innate and adaptive immunity. Therefore, vaccine vectors can significantly influence the magnitude and breadth, as well 
as the phenotypic and functional qualities of vaccine-induced immune responses. Moreover, as the type of delivery vector, in conjunction with the route of vaccine administration often determine whether or not vaccine-specific immune responses persist within the systemic and/or mucosal compartments (Masopust et al., 2001; Kiyono and Fukuyama, 2004; Ranasinghe et al., 2007; Czerkinsky and Holmgren, 2012), vector choice remains a critical determinant of the overall efficacy of any given vaccine. A part from the immunostimulatory potential to induce strong and persistent immunity, several other factors such as stability and ease of large scale manufacturing, safety, capacity for transgene insertion and pre-existing immunity also influence vector choice. It is now well-documented that pre-existing anti-vector immunity (especially neutralizing antibodies) can prevent transduction and/or expression of vaccine transgenes thus reducing vaccinespecific immune induction (Xiang et al., 2002; Fitzgerald et al., 2003; Lasaro and Ertl, 2009). This is a common phenomenon, clearly demonstrated with certain vectors which show superior immunogenicity in animal models yet induce only modest immune responses due to neutralization by pre-existing antibodies in humans (McCoy et al., 2007). Additionally, pre-existing immunity can alter the natural course of infection leading to catastrophic consequences such as enhanced HIV acquisition and possibly accelerated disease progression (Buchbinder et al., 2008; McElrath et al., 2008). Thus strategies that concurrently maximize vaccine immunogenicity while minimizing safety concerns remain an urgent priority in the development of a safe and efficacious vaccine for HIV/AIDS.

A good number of HIV vaccine candidates (both prophylactic and therapeutic) employing a broad range of vaccine delivery vectors have been tested and some have progressed to evaluation of potential efficacy in phase IIb/III trials. Of significant relevance as far as safety is the STEP trial that used human adenovirus serotype 5 (Ad5) to deliver a well-designed HIV immunogen expressing Gag/Pol/Nef, which was associated with increased risk of HIV acquisition in uncircumcised male vaccinees with pre-existing immunity to Ad5 (Buchbinder et al., 2008; McElrath et al., 2008). This unexpected and rather worrisome finding prompted the premature halting of two related efficacy trials due to futility (Gray et al., 2011; Hammer et al., 2013). As disappointing as this might have been at the time, invaluable lessons have been learned and there is still great optimism as these lessons are now taken on board. Focussing on some of the promising HIV vaccine candidates in preclinical and clinical development, this review discusses pertinent issues relating to safety and immunogenicity of replicating and nonreplicating viral vectors, pre-existing anti-vector immunity and how these can potentially influence the natural history of HIV infection and progression. In particular, this article highlights the safety profiles, immuno-stimulatory potential and possible limitations of plasmid DNA, MVA (modified vaccinia virus Ankara), ALVAC (canarypox virus), NYVAC (New York attenuated vaccinia virus), influenza virus and adenovirus vectored vaccines in preclinical and clinical studies for HIV vaccines. Some of the delivery vectors evaluated in clinical studies are summarized in Table 1, while those in preclinical development are summarized in Table 2.

\section{RECOMBINANT DNA VACCINE VECTORS}

DNA plasmid vaccines can induce both $\mathrm{T}$ and $\mathrm{B}$ cell immune responses, and are popular for their safety, stability, versatility and ease of large scale production. Most importantly is the fact that they can be used repetitively to boost immunity (Valentin et al., 2010) without the risk of immune interference as is the case with viral vectors with high prevalence of pre-existing immunity. However, on their own DNA plasmid vaccines have exhibited very limited immunostimulatory capacity and often induced suboptimal immune responses. Recent advances in DNA delivery such as intramuscular, skin or intradermal electroporation (Selby et al., 2000; Widera et al., 2000; Brave et al., 2010; Vasan et al., 2011; Kopycinski et al., 2012) or use of other physical delivery methods such as gene gun and biojector devices (Drape et al., 2006; Wang et al., 2008a; Graham et al., 2013), together with concurrent use of cytokine adjuvants including IL-2, IL12, and IL-15 (Winstone et al., 2011; Kalams et al., 2012, 2013) have greatly improved the immunogenic potential of DNA vaccines. In particular, IL-12 was shown to significantly augment the frequency, magnitude and breadth of Gag-specific immune responses in healthy volunteers immunized with a recombinant DNA vaccine expressing HIV-1 Gag (Kalams et al., 2012, 2013). Similarly, when macaques were co-immunized with a plasmid encoding IL-12 and a DNA plasmid expressing SIV-Gag, strong antibody and cellular responses which correlated with a better clinical outcome were induced (Boyer et al., 2005; Chong et al., 2007). More impressively, co-delivery of a plasmid encoding GMCSF with a DNA vaccine expressing SIV genes induced strong neutralizing antibody responses and ADCC, which protected against infection with SIVsmE660 (Lai et al., 2011). The use of strong adjuvants such as glucopyranosyl lipid A (a TLR4 agonist) in a DNA/MVA/protein immunization regimen was shown to enhance both antibody and T cell responses (McKay et al., 2014), while plasmids encoding the TLR5 agonist, flagellin, enhanced both antibody and $\mathrm{T}$ cell immunity to influenza virus (Applequist et al., 2005)

Other significant improvements in DNA vaccine technology include codon optimization, use of stronger promoters/enhancers and signal peptides such as the tissue plasminogen activator (tPA) and lysosome associated membrane protein (LAMP1), all of which significantly enhance transgene expression and trafficking, thus leading to increased vaccine immunogenicity (Wang et al., 2006a; Yan et al., 2007; Wallace et al., 2013). Furthermore, ease of DNA manipulation provides a platform to deliver polyvalent or multi-gene vaccine components which can increase the breadth and depth of vaccine-induced immunity to reduce immune escape. This strategy showed remarkable success in rabbit experiments where a polyvalent gp120 vaccine induced broadly neutralizing antibody responses as opposed to the monovalent vaccine (Wang et al., 2006b). Similarly, polyvalent mosaic plasmid DNA vaccines have demonstrated enhanced immunogenicity in mice (Kong et al., 2009) and rhesus monkeys (Santra et al., 2010).

Several studies indicate that delivery of DNA vaccines by electroporation induces both cellular and humoral immune responses which are long-lived and can persist for several years with or without subsequent heterologous boosting (Cristillo et al., 
Table 1 | Representative clinical studies.

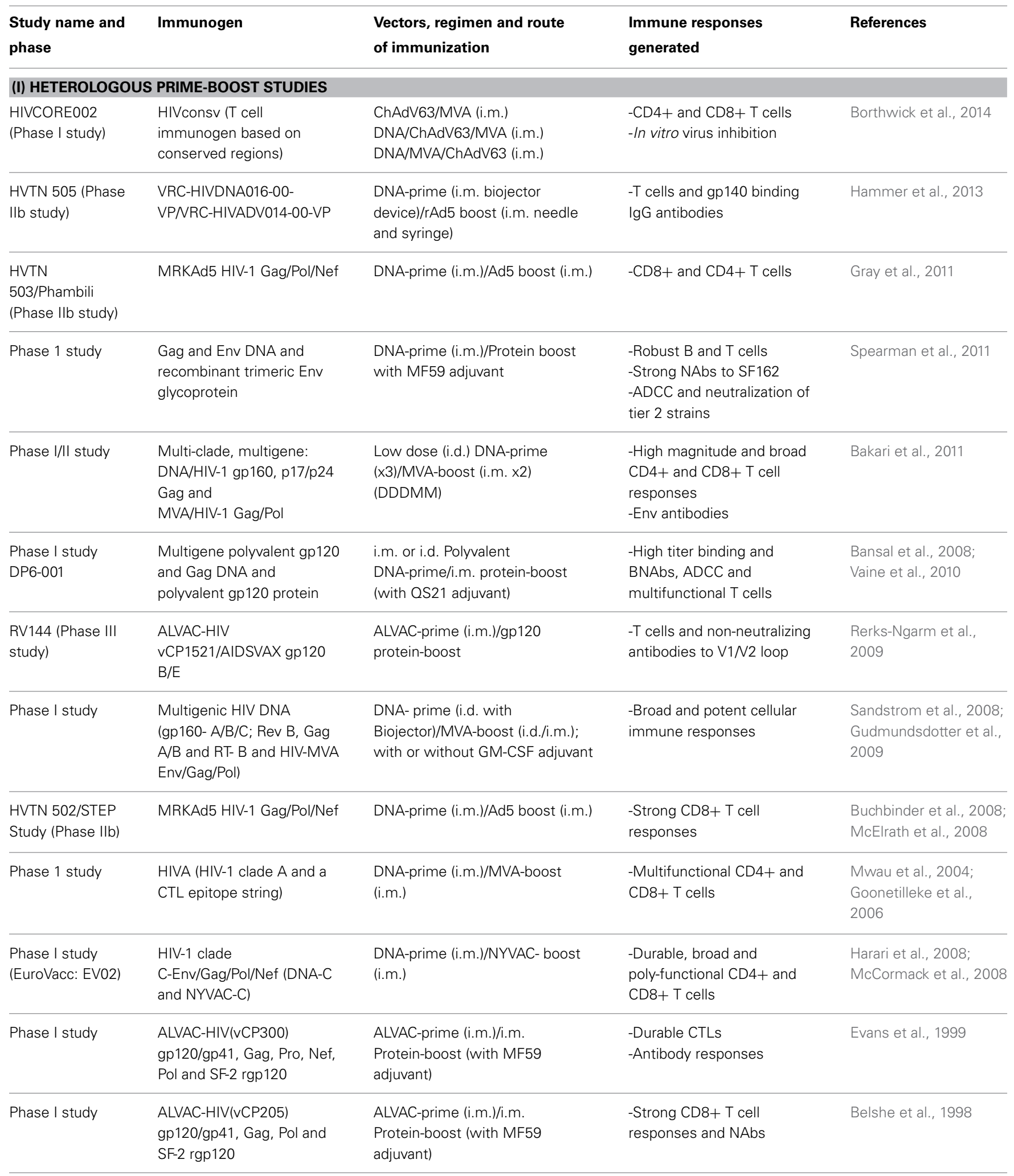


Table 1 | Continued

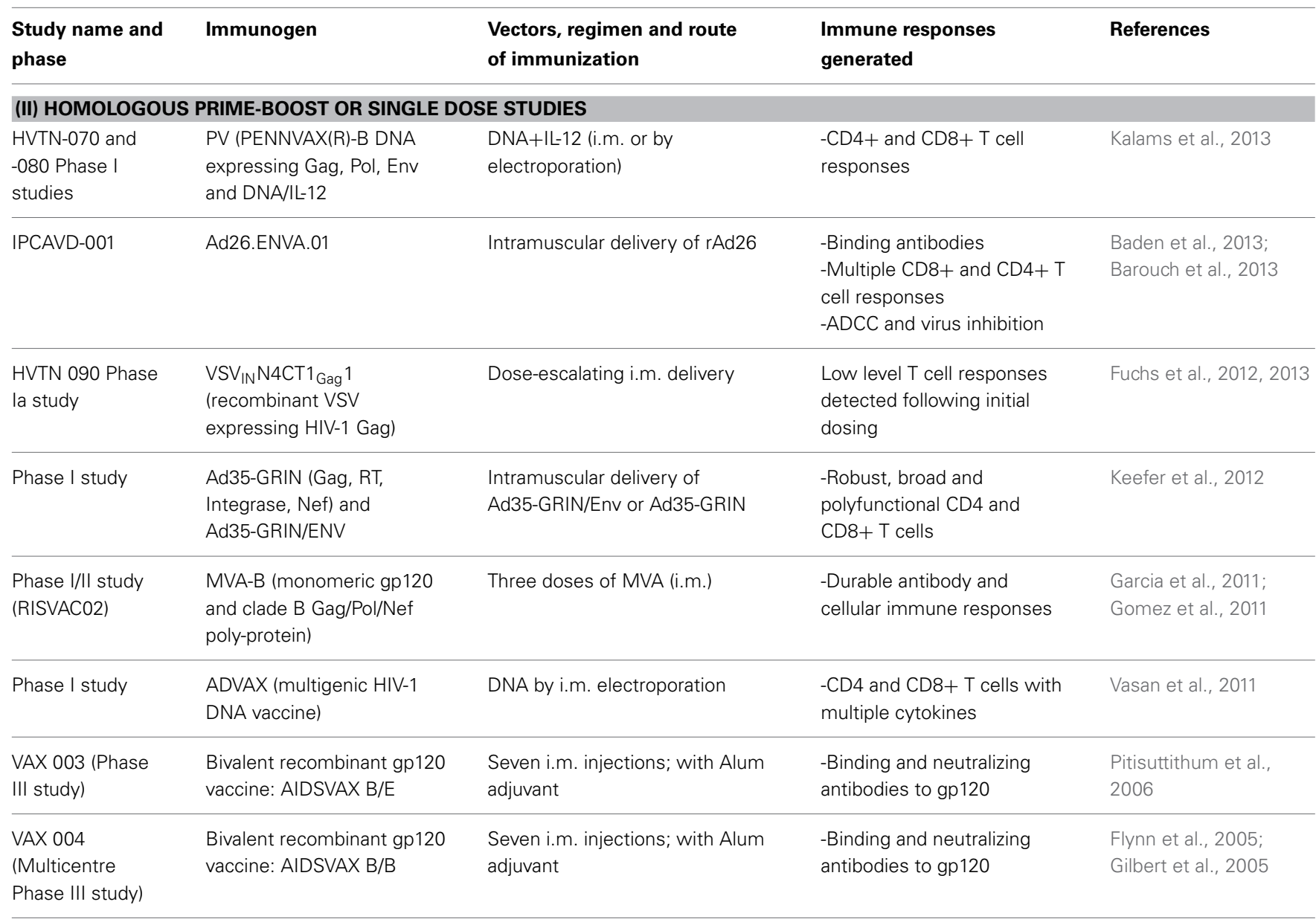

i.m., intramuscular; i.n., intranasal; i.d., intradermal; s.c., subcutaneous; i.p., intraperitoneal; ADCC, antibody dependent cytotoxicity; NAbs, neutralizing antibodies; BNAbs, broadly neutralizing antibodies.

2008; Patel et al., 2010; Jalah et al., 2014). In particular, the level of HIV-specific immune responses to the multigenic ADVAX vaccine was increased by up to 70-fold when electroporation was used for delivery (Vasan et al., 2011). Nonetheless, DNA vaccines consistently show much better immunogenicity when used as priming components in conjunction with viral vectors such as adenoviruses (Shiver et al., 2002; Hammer et al., 2013; Borthwick et al., 2014), MVA (Sandstrom et al., 2008; Gudmundsdotter et al., 2009; Bakari et al., 2011; Borthwick et al., 2014), fowlpox (Kent et al., 1998), and NYVAC (Hel et al., 2001) in heterologous prime boost regimens delivering the same vaccine inserts, or in coimmunization strategies that combine DNA-prime with protein boosting (Kennedy et al., 2008; Wang et al., 2008b). As a matter of fact, prime-boost regimens still remain the most successful strategies that emphasize the potential of DNA vaccines. It was recently shown that a DNA-prime/protein-boost regimen was significantly better than either DNA/DNA or protein/protein alone regimens for generating long-term protection of mice against Leishmania donovani (Mazumder et al., 2011). The DNA and protein co-immunization modalities are particularly desirable as they maximize induction of long-lived humoral and cellular immune responses which can disseminate to mucosal sites, including the genito-rectal mucosae (Patel et al., 2013; Jalah et al., 2014). A recent study has demonstrated in small animal models that concurrent, multiple-route DNA vaccinations comprising DNA prime by electroporation, followed with intranasal, intramuscular, subcutaneous or transcutaneous homologous protein boost induced strong HIV-specific B and T cell responses (Mann et al., 2014). Independently, another study showed enhancement of HIV gp120-specific IgA responses in serum and mucosal secretions following a DNA env-prime and gp120 protein-boost delivered with novel carbohydrate-based adjuvants (Advax-M and Advax-P) which were specifically designed for mucosal and systemic immune enhancement (Cristillo et al., 2011). The tremendous effect of a DNA prime in enhancing antibody responses to protein vaccines was also documented in a Phase 1 clinical study, where intramuscular delivery of a DNA priming vaccine followed with recombinant protein boost stimulated higher frequencies of $\mathrm{B}$ and $\mathrm{T}$ cells, as well as higher neutralizing antibody titres and ADCC in contrast to immunization with protein alone (Spearman et al., 2011). Perhaps the most exciting of the DNA-prime/protein-boost studies is the 6-plasmid polyvalent 
Table 2 | Representative preclinical studies.

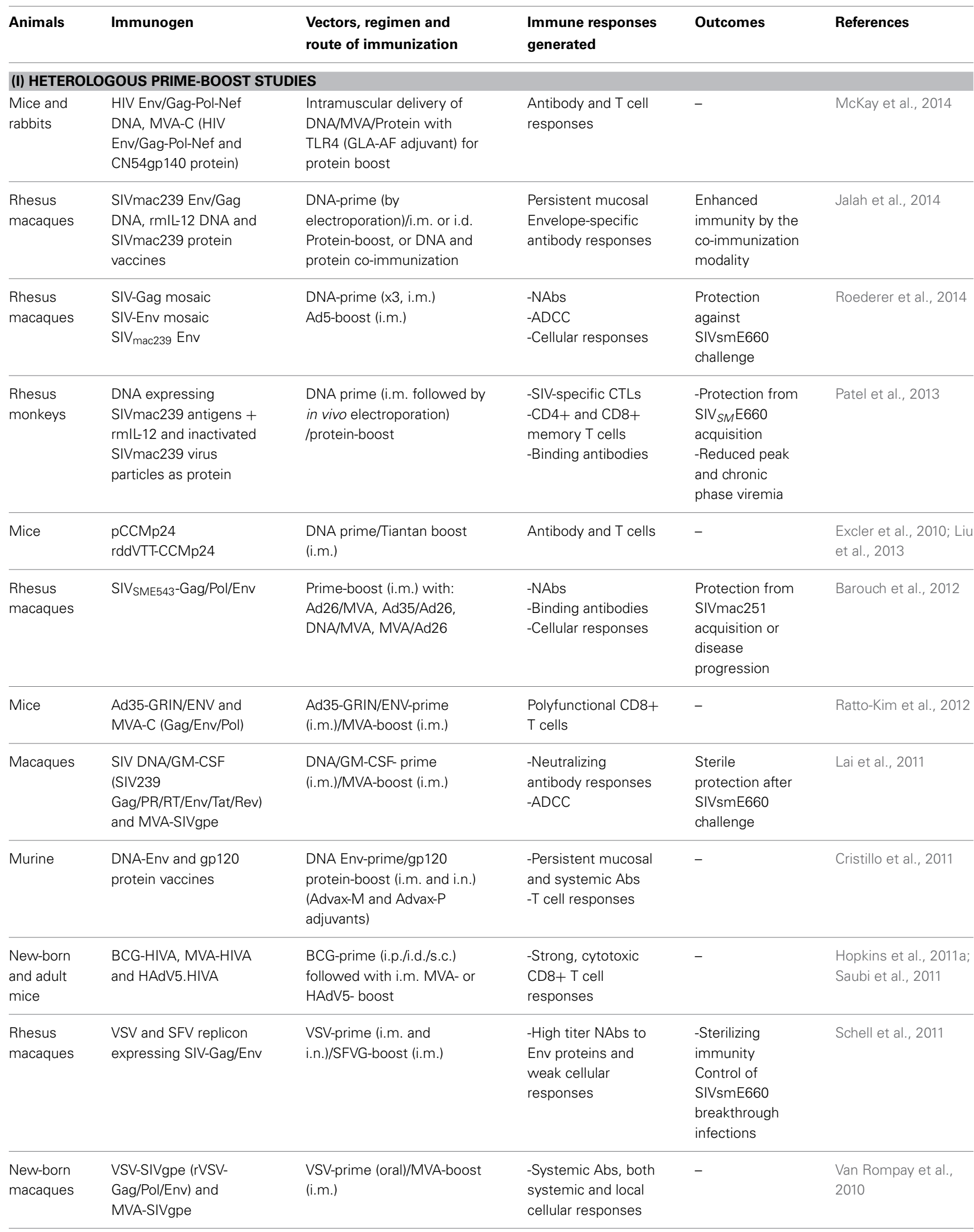


Table 2 | Continued

\begin{tabular}{|c|c|c|c|c|c|}
\hline Animals & Immunogen & $\begin{array}{l}\text { Vectors, regimen and } \\
\text { route of immunization }\end{array}$ & $\begin{array}{l}\text { Immune responses } \\
\text { generated }\end{array}$ & Outcomes & References \\
\hline $\begin{array}{l}\text { Mice, } \\
\text { rabbits and } \\
\text { macaques }\end{array}$ & $\begin{array}{l}\text { Consensus or Polyvalent } \\
\text { mosaic DNA and protein } \\
\text { (gp120) vaccines }\end{array}$ & $\begin{array}{l}\text { DNA-prime (i.m.)/i.m. and i.d. } \\
\text { rVaccinia-boost. } \\
\text { DNA-prime (gene gun)/ } \\
\text { Protein-boost (i.d.) + IFA }\end{array}$ & $\begin{array}{l}\text {-Broadly neutralizing } \\
\text { antibodies and CD8+ } \\
T \text { cell responses }\end{array}$ & $\begin{array}{l}\text { Enhanced } \\
\text { immunogenicity }\end{array}$ & $\begin{array}{l}\text { Wang et al., 2006b; } \\
\text { Santra et al., } 2010\end{array}$ \\
\hline $\begin{array}{l}\text { Rabbits } \\
\text { macaques }\end{array}$ & HIV-1 Env gp120 & $\begin{array}{l}\text { DNA (electroporation)/gp120 } \\
\text { protein boost }\end{array}$ & $\begin{array}{l}\text {-Persistent Th1, CTL } \\
\text { and Env responses }\end{array}$ & $\begin{array}{l}\text { Neutralization of } \\
\text { sensitive SHIV } \\
\text { isolates }\end{array}$ & Cristillo et al., 2008 \\
\hline $\begin{array}{l}\text { Rhesus } \\
\text { Macaques }\end{array}$ & $\begin{array}{l}\text { replication-defective } \\
\text { SHIV particles and } \\
\text { MVA-SHIV (SIV Gag, SIV } \\
\text { Pol and HIV Env) }\end{array}$ & $\begin{array}{l}\text { Intrarectal DNA prime/MVA } \\
\text { boost }\end{array}$ & $\begin{array}{l}\text {-Antibodies in } \\
\text { plasma } \\
\text {-Cellular responses }\end{array}$ & $\begin{array}{l}\text {-Preserved CD4 } \\
\text { T cells -Reduced } \\
\text { disease } \\
\text { progression after } \\
\text { SHIV 89.6P } \\
\text { challenge }\end{array}$ & Wang et al., 2004 \\
\hline $\begin{array}{l}\text { Rhesus } \\
\text { macaques }\end{array}$ & $\begin{array}{l}\text { SHIV-DNA plus IL-2 and } \\
\text { rMVA }\end{array}$ & $\begin{array}{l}\text { DNA + IL-12-prime } \\
\text { (i.n.)/MVA-boost (i.n.) }\end{array}$ & $\begin{array}{l}\text {-Mucosal and } \\
\text { systemic antibody } \\
\text { and cellular } \\
\text { responses }\end{array}$ & $\begin{array}{l}\text { Protection from } \\
\text { SHIV 89.6P } \\
\text { challenge }\end{array}$ & Bertley et al., 2004 \\
\hline Mice & $\begin{array}{l}\text { HIV-1 Env IIIB Ag } \\
\text { (DNA-Env and MVA-Env) }\end{array}$ & $\begin{array}{l}\text { DNA-Env-prime/MVA-Env- } \\
\text { boost (i.n. with Cholera toxin } \\
\text { adjuvant) }\end{array}$ & $\begin{array}{l}\text {-Mucosal CD8+ T } \\
\text { cells, mucosal and } \\
\text { systemic antibodies } \\
\text {-Beta-chemokines }\end{array}$ & - & Gherardi et al., 2004 \\
\hline $\begin{array}{l}\text { Rhesus } \\
\text { monkeys }\end{array}$ & $\begin{array}{l}\text { DNA, MVA and Ad5 } \\
\text { vectors expressing } \\
\text { SIVmac239 Gag }\end{array}$ & $\begin{array}{l}\text { DNA Prime (i.m.)/MVA- or } \\
\text { Ad5- boost (i.m.) }\end{array}$ & $\begin{array}{l}\text {-Robust CD8+ T } \\
\text { cells with cytotoxic } \\
\text { activity }\end{array}$ & $\begin{array}{l}\text { Pronounced } \\
\text { attenuation of } \\
\text { SHIV infection } \\
\text { and mitigated } \\
\text { disease } \\
\text { progression }\end{array}$ & Shiver et al., 2002 \\
\hline Macaques & $\begin{array}{l}\text { DNA and NYVAC SIV-gpe } \\
\text { (Gag/Pol/Env) }\end{array}$ & $\begin{array}{l}\text { DNA-prime } \\
\text { (i.m.)/NYVAC-boost (i.m.) }\end{array}$ & $\begin{array}{l}\text {-Durable CD8+ T cell } \\
\text { responses }\end{array}$ & - & Hel et al., 2001 \\
\hline \multicolumn{6}{|c|}{ (II) HOMOLOGOUS PRIME-BOOST OR SINGLE DOSE STUDIES } \\
\hline $\begin{array}{l}\text { Mice and } \\
\text { rabbits }\end{array}$ & $\begin{array}{l}\text { Ad4Env160 } \\
\text { Ad4Env140 } \\
\text { Ad4Env120 }\end{array}$ & $\begin{array}{l}\text { i.m., i.n., or s.c. delivery of } \\
\text { rAd4 }\end{array}$ & $\begin{array}{l}-T \text { cell and antibody } \\
\text { responses }\end{array}$ & $\begin{array}{l}\text { Neutralization of } \\
\text { tier-1 and tier-2 } \\
\text { pseudoviruses }\end{array}$ & Alexander et al., 2013 \\
\hline
\end{tabular}


Table 2 | Continued

\begin{tabular}{|c|c|c|c|c|c|}
\hline Animals & Immunogen & $\begin{array}{l}\text { Vectors, regimen and } \\
\text { route of immunization }\end{array}$ & $\begin{array}{l}\text { Immune responses } \\
\text { generated }\end{array}$ & Outcomes & References \\
\hline Mice & $\begin{array}{l}\text { Ad35-GRIN/ENV and } \\
\text { MVA-Gag/Env/Pol }\end{array}$ & $\begin{array}{l}\text { Ad35-prime (i.m.)/Ad35-boost } \\
\text { i.m.): MVA-prime } \\
\text { (i.m.)/MVA-boost (i.m.) }\end{array}$ & $\begin{array}{l}\text {-Polyfunctional CD8+ } \\
\text { T cells }\end{array}$ & - & Ratto-Kim et al., 2012 \\
\hline $\begin{array}{l}\text { Rhesus } \\
\text { macaques }\end{array}$ & SIV $_{\text {SME543-Gag/Pol/Env }}$ & $\begin{array}{l}\text { MVA-prime (i.m.)/MVA-boost } \\
\text { (i.m.) }\end{array}$ & $\begin{array}{l}\text {-Neutralizing Abs, } \\
\text { binding antibodies } \\
\text { and cellular } \\
\text { responses }\end{array}$ & $\begin{array}{l}\text { Protection from } \\
\text { SIVmac251 } \\
\text { acquisition or } \\
\text { disease } \\
\text { progression }\end{array}$ & Barouch et al., 2012 \\
\hline $\begin{array}{l}\text { Rhesus } \\
\text { macaques }\end{array}$ & $\begin{array}{l}\text { RhCMV-SIV/Gag, } \\
\text { Rev/Nef/Tat, Pol, Env }\end{array}$ & $\begin{array}{l}\text { RhCMV vectors delivered by } \\
\text { s.c. injection }\end{array}$ & $\begin{array}{l}\text {-Strong and } \\
\text { persisting, } \\
\text { polyfunctional } \\
\text { effector memory } \\
\text { CD8+ and CD4+ } \\
\text { cells }\end{array}$ & $\begin{array}{l}\text { Viral clearance } \\
\text { and durable } \\
\text { protection from } \\
\text { SIVmac239 } \\
\text { disease } \\
\text { progression }\end{array}$ & $\begin{array}{l}\text { Hansen et al., 2009, } \\
2011\end{array}$ \\
\hline $\begin{array}{l}\text { Rhesus } \\
\text { monkeys }\end{array}$ & $\begin{array}{l}\text { SIV-Gag, SIV-Env and SIV } \\
\text { Rev-Tat-Nef fusion } \\
\text { protein }\end{array}$ & $\begin{array}{l}\text { Intravenous delivery of } \\
\text { recombinant Rhadinovirus }\end{array}$ & $\begin{array}{l}\text {-Persistent effector } \\
\text { memory CD8+ } T \\
\text { cells }\end{array}$ & $\begin{array}{l}\text { Control of } \\
\text { SIVmac239 } \\
\text { replication }\end{array}$ & Bilello et al., 2011 \\
\hline $\begin{array}{l}\text { Rhesus } \\
\text { macaques }\end{array}$ & $\begin{array}{l}\text { Rabies virus (RV) } \\
\text { expressing SIVmac239 } \\
\text { Gag/Pol or Env }\end{array}$ & $\begin{array}{l}\text { Intramuscular delivery of rRV } \\
\text { constructs }\end{array}$ & $\begin{array}{l}\text {-Polyfunctional CD8+ } \\
\text { T cells in the mucosa } \\
\text {-NAbs }\end{array}$ & $\begin{array}{l}\text { Control of } \\
\text { SIVmac251-CX } \\
\text { challenge }\end{array}$ & Faul et al., 2009 \\
\hline $\begin{array}{l}\text { Rhesus } \\
\text { and } \\
\text { Cynomolgus } \\
\text { macaques }\end{array}$ & $\begin{array}{l}\text { SIV-Gag DNA + rIL-12 } \\
\text { DNA vaccines }\end{array}$ & Intramuscular DNA delivery & $\begin{array}{l}\text { T cell and Antibody } \\
\text { responses }\end{array}$ & $\begin{array}{l}\text { Improved clinical } \\
\text { outcome after } \\
\text { SHIV[89.6P] } \\
\text { challenge }\end{array}$ & $\begin{array}{l}\text { Boyer et al., 2005; } \\
\text { Chong et al., } 2007\end{array}$ \\
\hline Mice & $\begin{array}{l}\text { HIV-1 Env IIIB Ag } \\
\text { (DNA-Env and MVA-Env) }\end{array}$ & $\begin{array}{l}\text { MVA-Env/MVA-Env } \\
\text { DNA-Env/DNA-Env (i.n. with } \\
\text { Cholera toxin adjuvant) }\end{array}$ & $\begin{array}{l}\text {-Mucosal CD8+ } T \\
\text { cells, mucosal and } \\
\text { systemic antibodies } \\
\text {-Beta-chemokines }\end{array}$ & - & Gherardi et al., 2004 \\
\hline Mice & $\begin{array}{l}\text { Influenza virus } \\
\text { expressing HIV-1 } \\
\text { ELDKWA epitope }\end{array}$ & $\begin{array}{l}\text { i.n. prime/boost with chimeric } \\
\text { influenza virus, followed with } \\
\text { i.p. boost with live virus }\end{array}$ & $\begin{array}{l}\text {-Neutralizing } \\
\text { antibodies }\end{array}$ & $\begin{array}{l}\text { Neutralization of } \\
\text { distantly related } \\
\text { HIV-1 isolates }\end{array}$ & Muster et al., 1994 \\
\hline
\end{tabular}

i.m., intramuscular; i.n., intranasal; i.d., intradermal; s.c., subcutaneous; i.p., intraperitoneal; ADCC, antibody dependent cytotoxicity; NAbs, neutralizing antibodies; BNAbs, broadly neutralizing antibodies.

DNA vaccine expressing gp120 and Gag, followed by QS21adjuvanted polyvalent gp120 protein boost (DP6-001 study) in which multifunctional $\mathrm{T}$ cells and high-titre gp120-specific binding and broadly-neutralizing antibodies as well as ADCC were induced (Graham et al., 2006; Bansal et al., 2008; Wang et al., 2008b; Vaine et al., 2010).

Apart from effective delivery strategies and routes of immunization, there is evidence showing that expression of DNA vaccines and subsequent immunogenicity in humans and other primates can be limited by serum amyloid P component (SAP), a protein found in blood and known to bind strongly to DNA (Wang et al., 2011, 2012). In small animals this protein either binds weakly or does not exist at all. Thus, depletion of SAP protein prior to administration of DNA vaccines is another new strategy being tested to improve DNA vaccine immunogenicity. This concept has been proven in mice, where depletion of SAP using the bis-d-proline compound CPHPC (Bodin et al., 2010; Gillmore et al., 2010) was shown to augment antibody and cellular immune responses to a DNA vaccine expressing Hepatitis B surface antigens (Wang et al., 2012). The concept is currently 
being tested in a Phase 1 clinical trial (HIVCORE003) of healthy adults using the T-cell based HIV candidate vaccine, HIVconsv.

Although the efficacy of an HIV DNA vaccine is yet to be demonstrated in humans, various studies (prophylactic and therapeutic) in the macaque model have reported protective immune responses which controlled SIV/SHIV replication or protected from infection (Rosati et al., 2005, 2009; von Gegerfelt et al., 2007; Valentin et al., 2010; Patel et al., 2013). In particular, a study combining a DNA/MVA mucosal delivery of a DNA construct expressing replication-defective SHIV particles and MVA expressing SIV-Gag/Pol and HIV Env (MVA-SHIV) demonstrated significant protection from disease progression after a SHIV89.6P challenge (Wang et al., 2004). Furthermore, mucosal co-delivery of a DNA priming vaccine together with an IL-2 encoding vector, followed by MVA boost also induced protective immunity against SHIV89.6P challenge (Bertley et al., 2004). The results in these macaque models, together with the documented efficacy of DNA vaccines against animal diseases [e.g., equine West Nile Virus (WNV) (Davis et al., 2001), melanoma in dogs (Bergman et al., 2003) and infectious hematopoietic necrosis virus (IHNV) in salmon (Garver et al., 2005; Kurath et al., 2006)] raise hopes that with the right immunogen and effective delivery strategies (including adjuvants), plasmid DNA vaccines for HIV/AIDS could achieve efficacy in clinical trials, when used alone, but more realistically in prime-boost combinations with live viral-vectored or protein vaccines.

\section{NON-REPLICATING RECOMBINANT VIRAL VECTORS ADENOVIRUS VACCINE VECTORS}

Adenoviruses are the most powerful vectors for inducing both antibody and cell-mediated immunity to inserted transgenes and are known to elicit between 5- and 10-fold stronger $\mathrm{T}$ cell responses compared to conventional naked DNA or MVA/poxlike virus vectors (Xiang et al., 1996; He et al., 2000; Fitzgerald et al., 2003; Casimiro et al., 2003a, 2004; Tatsis and Ertl, 2004; Catanzaro et al., 2006). The Adenovirus vectors use either the Coxsackie and Adenovirus Receptor (CAR) or CD46 receptors (Bergelson et al., 1997; Gaggar et al., 2003) and can infect a wide variety of cells, including dendritic cells. In particular, group B adenoviruses such as Ad35 recognize CD46 surface protein and infect DCs more efficiently than group $\mathrm{C}$ isolates. These vectors achieve higher levels of transgene expression which in turn results in stronger and persistent immune effector functions (Zhang et al., 2001; Hutnick et al., 2010; Suleman et al., 2011). Several studies indicate that adenoviruses predominantly stimulate persistent effector memory CD8+ $\mathrm{T}$ cell responses (Yang et al., 2003a, 2007a; Tatsis et al., 2007a) which are more suitable for immediate control of invading pathogens at peripheral entry sites such as the genital mucosa (Cerwenka et al., 1999; Sallusto et al., 2004; Huster et al., 2006), and have shown tremendous success in animal studies (Liu et al., 2009). In addition to the effector memory $\mathrm{T}$ cells, stable central memory CD8 $+\mathrm{T}$ cell populations are also generated, thus providing surveillance in both peripheral and lymphoid sites. Although persisting adenovirus-driven immune responses could also be due to the long-term presentation of antigens by non-haematopoietic cells serving as unlimited antigen depot (Finn et al., 2009; Kim et al., 2010; Bassett et al.,
2011), long-lived immunity is largely attributed to persisting lowlevel expression of inserted immunogens. Adenovirus genomes are known to persist for prolonged periods in various cell types (including those at inoculation sites) where they remain transcriptionally active and continuously produce low-levels of antigen to prime naïve $\mathrm{T}$ cells while also maintaining the effector memory T cells (Yang et al., 2006, 2007b; Tatsis et al., 2007a). Furthermore, the arising effector memory $\mathrm{T}$ cells express the IL-7 receptor (CD127) which allows their prolonged survival in the absence of antigen. Besides induction of potent adaptive immune responses, adenoviruses also stimulate innate immunity via highly inflammatory responses which involve TLR2, TLR9, NOD-like receptors and the type 1 interferon pathways that result in abundant cytokine and chemokine secretion (Hensley et al., 2005; Nazir and Metcalf, 2005; Appledorn et al., 2008; Muruve et al., 2008). Another attractive feature of adenovirus vectors is their ability to induce both systemic and mucosal immune responses following parenteral delivery, as well as their suitability for mucosal immunization (Sharpe et al., 2002; Xiang et al., 2003; Bangari and Mittal, 2006; Haut et al., 2010).

The most well-characterized of the adenovirus vectors is human Ad5, successfully used as a delivery vector for a rabies vaccine and found to be very good at inducing protective virus neutralizing antibodies concurrently with CD8+ and CD4+ T cells (Xiang et al., 1995, 1996). In the HIV field, Ad5 was used as a booster immunization following DNA priming and induced strong CD8 $+\mathrm{T}$ cell responses in a large proportion of the STEP study vaccinees (Buchbinder et al., 2008; McElrath et al., 2008). However, clinical efficacy may have been significantly compromised by pre-existing neutralizing antibodies (ranging from 40 to $70 \%$ in developed countries and greater than $90 \%$ in developing countries) and cellular immunity (Fitzgerald et al., 2003; Holterman et al., 2004; Bangari and Mittal, 2006; Xiang et al., 2006; Lasaro and Ertl, 2009; Ersching et al., 2010; Mast et al., 2010; Barouch et al., 2011). These results were recapitulated in a non-human primate study using low-dose penile exposure to SIVmac251 in Ad5 seropositive animals immunized with SIVGag/Pol/Nef (Qureshi et al., 2012). Possibly, adenovirus vaccination boosted the numbers of activated CD4+ T cells which are targets for HIV-1 (Benlahrech et al., 2009). While this might seem a plausible explanation, especially when considering the potential of such activated targets to traffic to the genito-rectal mucosae (Tatsis et al., 2007a; Benlahrech et al., 2009), this argument is strongly contested by observations that other vaccine carriers such as DNA and MVA do stimulate CD4+ T cell activation but have not been associated with increased HIV acquisition. However, it is worth noting that DNA/MVA vaccines are yet to be tested for efficacy in large clinical trials and as such their potential to enhance HIV acquisition has never assessed. Furthermore, DNA/MVA vaccines combinations have not been associated with long-term persistence of activated $\mathrm{T}$ cells or mucosal homing. Another postulated theory is the formation of adenovirus-specific antibody immune complexes that activate both dendritic and CD4+ $\mathrm{T}$ cells hence fuelling infection (Perreau et al., 2008). In this study, Ad5 immune complexes were strongly correlated with higher HIV infection in the in vitro cultures, thus supporting a stronger likelihood of enhanced HIV acquisition. Should either 
or both of these theories be true, this would have dire consequences for other clinical trials using Ad5 to deliver non-HIV immunogens such as malaria (Sedegah et al., 2011; Tamminga et al., 2011; Chuang et al., 2013) and TB (Smaill et al., 2013) vaccines which will induce similar phenotypes and pre-dispose the vaccinees to increased HIV acquisition risk, although this may not be apparently detectable as these studies may not monitor HIV acquisition.

Apart from the issue of pre-existing immunity, immunization with Ad5 can induce neutralizing antibodies in naïve individuals which can be a hindrance for successive immunizations with the same or cross-reactive adenoviral vectors (Casimiro et al., 2003b; Bangari and Mittal, 2006). Thus new rare adenovirus vectors with lower pre-existing immunity such as Ad26 and Ad35 are becoming more attractive (Holterman et al., 2004; Abbink et al., 2007; Barouch et al., 2012; Zhang et al., 2013), although these are relatively less immunogenic compared to Ad5 (Colloca et al., 2012). Besides the lower sero-prevalence, Ad26 neutralizing antibody titres are usually very low compared to Ad5 (Abbink et al., 2007; Chen et al., 2010; Mast et al., 2010). As an HIV vaccine delivery vector, Ad26 was shown to induce broadly functional cellular and antibody responses with viral inhibitory capacity in a first-in-human (IPCAVD-001) clinical trial of an HIV envelope immunogen (Ad26.ENVA.01) (Baden et al., 2013; Barouch et al., 2013). In this study, a dose-dependent expansion of the magnitude, breadth, and epitopic diversity of Envspecific binding antibody responses were observed. The responses comprised multiple CD8+ and CD4+ T cell memory subpopulations and cytokine secretion phenotypes. Antibody-dependent cell-mediated phagocytosis and degranulation functional activity were also observed. Ad35 has also shown high immunogenicity in healthy volunteers, eliciting robust and polyfunctional CD8+ and CD4+ $\mathrm{T}$ cells in a majority of volunteers immunized with Ad35-GRIN (an immunogen based on Gag, RT, integrase and nef) or Ad35-GRIN/ENV (premixed Ad35-GRIN and Ad35-ENV vaccines) (Keefer et al., 2012). Similarly, in BALB/c mice, an Ad35-GRIN/ENV-prime followed by a boost with rMVA containing Gag/Env/Pol genes from various HIV-1 clades induced polyfunctional CD8+ Gag-specific central and effector memory $\mathrm{T}$ cells which were superior to those elicited in homologous Ad35/Ad35 or MVA/MVA prime boosts (Ratto-Kim et al., 2012).

Other rare adenovirus vectors include human Ad6, chimpanzee Ad3, Ad63, and Ad68 (Barnes et al., 2012; Colloca et al., 2012; Dicks et al., 2012; O’Hara et al., 2012; Roshorm et al., 2012). The chimpanzee adenoviruses remain attractive in particular due to their high immunological potency and low sero-prevalence, as well as extremely low or virtually absent cross-reactivity with human adenoviruses (Xiang et al., 2006; Chen et al., 2010; Colloca et al., 2012). Furthermore, chimpanzee adenoviruses induce stronger $\mathrm{T}$ and $\mathrm{B}$ cell responses in heterologous primeboost regimens even in the presence of pre-existing immunity to Ad5 (Tatsis et al., 2009). Apart from using these naturally occurring human and chimpanzee adenoviruses, new derivatives of adenovirus vectors that have equivalent immunogenicity but with significantly lower pre-existing antibodies are currently being developed (Dicks et al., 2012; Lopez-Gordo et al., 2014). However, it is worth noting that pre-existing cellular immunity $(\mathrm{CD} 8+$ and
CD4+ T cells) may be a major deterrent as unlike antibodies, these cells are highly cross-reactive across adenovirus serotypes because they are directed to conserved sequences of adenovirus (Olive et al., 2002; Fitzgerald et al., 2003; Frahm et al., 2012). Nevertheless, some studies indicate that Ad5 and Ad26 vectors can still elicit significant systemic and mucosal responses even in people with pre-existing immunity (Barouch et al., 2013; Smaill et al., 2013). Immunogenic adenoviruses faced with significant pre-existing immunity problems can be improved by modification of the antibody-binding sites, especially within the variable hexon loops in order to reduce NAb binding whilst maintaining immunogenicity (Bruder et al., 2012). This can be achieved via point mutations or complete replacement (Roberts et al., 2006; Abe et al., 2009; Pichla-Gollon et al., 2009; Bruder et al., 2013).

Besides their immunogenicity when used alone, adenovirus vaccines are also very immunogenic when used to prime responses which are then boosted by other vaccine vectors (Tatsis et al., 2007b; Ratto-Kim et al., 2012). In particular, adenovirusprime followed with MVA-boost can induce high frequencies of much more long-lived, potent $\mathrm{T}$ cells (Reyes-Sandoval et al., 2008, 2010; Capone et al., 2010; Hill et al., 2010). A Phase I clinical trial of a T-cell HIV vaccine based on the conserved regions was recently shown to elicit exceptionally high magnitude and polyfunctional $\mathrm{T}$ cell responses (circa 5000 IFN- $\gamma$ ELISPOT SFU/million cells) in HIV-negative healthy volunteers when primed with chimpanzee Ad63 (ChAdV63-HIVconsv) followed with MVA-HIVconsv boost (Borthwick et al., 2014). The vaccine-induced CD8 $+\mathrm{T}$ cells exhibited potent in vitro antiviral activity. This study also demonstrated that the magnitude and functional capacity of $\mathrm{T}$ cells induced in a regimen comprising three priming doses of DNA followed with ChAdV63 and MVA (DDDCM) did not differ significantly from those in a simplified ChAdV63-prime and MVA-boost (CM) regimen. The superior immunogenicity of this regimen is not unique to HIV immunogens, as it has also been demonstrated in preclinical and clinical studies of experimental malaria vaccines (Dunachie et al., 2006; Draper et al., 2010). Such repeated heterologous immunizations with the same transgene are known to increase both the magnitude and functional quality of vaccine-specific $\mathrm{T}$ cells and to allow more efficient migration to mucosal-associated tissues (Tatsis et al., 2007b). This is important in HIV infection, as effector immune cells in mucosal sites could block HIV transmission. It has also been shown that DNA priming followed with adenovirus boosting can reduce the level of anti-vector antibodies and increase transgene-specific immune responses (Xiang et al., 1999; Yang et al., 2003b), although this is questionable when considering the STEP study which employed a DNA-prime/Ad5-boost regimen. However, it is possible that this regimen effectively reduced the anti-vector antibody effect, thus curtailing a potentially worse outcome in the absence of DNA priming. Furthermore, prime-boost regimens with various combinations of adenovirus vectors were shown to induce robust frequencies of HIV-1 Gagspecific CD8 $+\mathrm{T}$ cells in nonhuman primates (Reyes-Sandoval et al., 2004), although it has to be appreciated that the level of pre-existing Ad5 immunity in NHPs would be lower or absent. 
Adenoviruses are only associated with benign human pathologies, but their greatest limitation is pre-existing immunity which dampens vaccine-specific immunity by limiting transgene expression, while potentially exacerbating HIV acquisition. However, all else considered, Adenoviruses remain by far the most promising vaccine carriers for HIV-1, because unlike other vectors, they induce exceptionally high and persistent frequencies of vaccine specific $\mathrm{T}$ cells, which is a requirement for sustained HIV control. Although their efficacy has probably been hampered by high sero-prevalence, this no longer seems an insurmountable hurdle in light of the enormous amount of research efforts directed at finding strategies to circumvent the problems of pre-existing immunity (Gabitzsch et al., 2009). Additionally, replicating adenoviruses such as AdH4 and AdHu7 which can be delivered orally in the form of edible capsules might help to overcome preexisting immunity (Xiang et al., 2003). Moreover, intranasal or oral delivery of adenoviruses has been shown to provide superior protection in animal models, and might trigger mucosal immune responses well-situated for preventing HIV acquisition. Perhaps adenovirus vectors engineered not to induce CD4+ T cells could be an alternative to overcome increased HIV-1 acquisition risk, although lacking CD4 $+\mathrm{T}$ cell help for the CD8+ $\mathrm{T}$ cells might compromise the differentiation and stability and thus efficacy of both CD8 + T cells and antibody responses (Yang et al., 2007b).

\section{RECOMBINANT MVA (rMVA) VECTORS}

Apart from their excellent safety profile, inherent adjuvant properties and ease of large scale production, recombinant vaccinia virus vectors are also popular for their large genomes which facilitate insertion of larger immunogens (Smith and Moss, 1983). MVA does not replicate in humans (Carroll and Moss, 1997) due to serial passaging in chick embryo fibroblasts which resulted in loss of more than $10 \%$ of its genome (Meyer et al., 1991), and its safety was well-documented during the smallpox eradication campaign (Mahnel and Mayr, 1994). MVA's potent immunostimulatory properties are achieved in a cascade of events involving induction of type 1 interferons, various chemokines for cell migration and activation of several cellular signaling pathways (Price et al., 2013). The immunostimulatory potency of MVA is largely attributed to the absence of genes involved in immune evasion (such as those that interfere with IFN- $\alpha$, IFN- $\beta$, and TNF- $\alpha$ ), thus allowing for stronger innate immunity to be generated (Antoine et al., 1998). MVA vectors are particularly important for generating strong $\mathrm{T}$ cell immunity against intracellular pathogens and cancers, but have also been shown to induce potent, high titre antibodies in a variety of disease models including SIV and malaria (Gherardi et al., 2003; Draper et al., 2008, 2013; Barouch et al., 2012). However, it is now well established that MVA vectors are more suited for boosting rather than priming, and depending on the priming vector (e.g., DNA or live vectors such as fowlpox and adenoviruses), MVA can induce various phenotypes of T cells, either predominated by $\mathrm{CD} 4+$ or $\mathrm{CD} 8+$ subsets or a combination of both.

In pre-clinical and clinical studies of malaria, recombinant MVA was shown to be highly immunogenic as it induced strong (and protective) cellular and antibody responses to malaria antigens, either on its own or when used to boost responses primed by vectors such as DNA, fowlpox or AdHu5 (Schneider et al., 1998, 1999; Gilbert et al., 1999, 2002; McConkey et al., 2003; Anderson et al., 2004; Webster et al., 2005; Bejon et al., 2007; Sheehy et al., 2011). Recombinant MVA85A (expressing the mycobacterial antigen Ag85A) was also shown to induce strong and durable $\mathrm{T}$ cell responses in various clinical studies (Scriba et al., 2012; Tameris et al., 2013, 2014). Furthermore, it was demonstrated that MVA expressing influenza A virus antigens (MVA-NP+M1) efficiently boosted $\mathrm{CD} 8+\mathrm{T}$ cell responses to achieve clinical efficacy in humans (Berthoud et al., 2011; Lillie et al., 2012). As a therapeutic vaccine for cancer, recombinant MVA expressing the human papilloma virus antigens E2, E6, or E7, with or without IL-12 was shown to induce $\mathrm{T}$ and $\mathrm{B}$ cell immunity resulting in controlled HPV load and subsequent regression or complete elimination of precancerous lesions in a majority of vaccinees (Corona Gutierrez et al., 2004; Garcia-Hernandez et al., 2006; Albarran et al., 2007). Additionally, MVA expressing 5T4 antigen (TroVax) induced 5T4specific antibody and cellular responses which correlated with tumor regression in a clinical trial of patients with advanced colorectal cancer (Harrop et al., 2006).

Although there is clear demonstration of the clinical efficacy of prophylactic and therapeutic MVA-vectored vaccines for malaria, $\mathrm{TB}$, influenza virus and cancer, MVA vaccines for HIV are yet to be evaluated for clinical efficacy. However, Phase I and II studies of MVA expressing HIV antigens, either alone or in various prime-boost combinations indicate modest to strong immunogenicity (Guimaraes-Walker et al., 2008; Howles et al., 2010; Bakari et al., 2011; Garcia et al., 2011; Goepfert et al., 2011; Gomez et al., 2011). In particular, the MVA-B candidate HIV vaccine expressing monomeric gp120 and Gag-Pol-Nef poly-protein of clade B where MVA was administered without prior priming, induced long-lasting robust and polyfunctional effector memory $\mathrm{T}$ cell and antibody responses in Phase I/II studies (Garcia et al., 2011; Gomez et al., 2011). Furthermore, MVA has shown much higher immunogenicity when combined in prime-boost regimens with other priming vectors such as DNA, fowlpox or adenovirus (Goepfert et al., 2011; Keefer et al., 2011; Borthwick et al., 2014). In Phase 1 studies of the HIVA immunogen (based on HIV clade A and a string of CTL epitopes), priming with DNA (pTHr.HIVA) followed with MVA boosting (MVA.HIVA) was found to be immunogenic, inducing multifunctional and proliferative CD8+ and CD4+ T cell responses in greater than $70 \%$ of the vaccinees (Mwau et al., 2004; Goonetilleke et al., 2006).

As discussed earlier, a Phase I study combining DNA- and/or ChAdV63-prime followed with MVA boost to deliver an HIV$1 \mathrm{~T}$ cell immunogen induced high magnitude $\mathrm{T}$ cell responses with potent antiviral capacity (Borthwick et al., 2014). This study and similar studies of malaria vaccines (Sheehy et al., 2011, 2012; O'Hara et al., 2012) showed that the magnitude of $\mathrm{T}$ cell responses induced by ChAdV63 alone were modest, but significant boosting was achieved following MVA administration, thus highlighting the superior immunogenic potential of MVA when combined with appropriate priming vectors such as BCG (Whelan et al., 2009; Scriba et al., 2012), natural influenza A virus (Berthoud et al., 2011) or ChAdV63 (Colloca et al., 2012). 
Remarkably, a DNA/MVA prime boost of a vaccine expressing multiple HIV antigens induced responses in about $90 \%$ of volunteers and demonstrated strong immunogenicity despite preexisting immunity to vaccinia virus (Sandstrom et al., 2008). As a therapeutic HIV vaccine vector, rMVA was found to be safe and to significantly augment HIV-specific CD4+ and CD8+ T cell responses in HAART-treated HIV-infected volunteers immunized with the MVA.HIVA candidate vaccine (Dorrell et al., 2006; Ondondo et al., 2006; Yang et al., 2007c). Furthermore MVA was found to be safe in neonates in a Phase 1 trial where MVA.HIVA was administered to infants born to HIV-infected or uninfected mothers (Afolabi et al., 2013). Therapeutic administration of MVA prime followed with fowlpox boost expressing Env, Gag, Tat, Rev, and Nef-RT fusion antigens increased the frequencies and breadth of $\mathrm{T}$ cell responses in young adults (Greenough et al., 2008).

One very attractive feature of rMVA (and other poxvirus vectors) is their ability to induce mucosal immune responses when administered via mucosal routes (Gherardi and Esteban, 1999, 2005). In particular, murine and macaques studies using rMVA vectors demonstrated induction of protective HIV-specific immune responses within the genito-rectal mucosae, which in some cases correlated with reduced disease progression (Belyakov et al., 1998a; Makitalo et al., 2004; Wang et al., 2004). Enhanced immunogenicity of rMVA in combination with DNA priming was also achieved by using the non-toxic B subunit of cholera toxin (CTB) as mucosal adjuvant (Gherardi et al., 2004). Thus, even though MVA may be inadequate as a stand-alone delivery platform, it definitely shows greater potential as a boosting vector (especially for the chimpanzee adenoviruses) and should be evaluated for efficacy in advanced HIV vaccine trials.

\section{RECOMBINANT NYVAC VACCINE VECTORS}

NYVAC vector is also a vaccinia-based vector which was highly attenuated by deletion of 18 genes involved in host range virulence. It has been shown to induce mainly CD4+ $\mathrm{T}$ cell responses, in contrast to MVA which has a stronger immunostimulatory potential and is known to induce both CD8+ and CD4+ responses (Mooij et al., 2008). However, in a trial of chronically infected patients on HAART, a NYVAC-based vaccine expressing Gag/Pol/Nef/Env from an HIV-1 clade B isolate (NYVAC-B) was found to be highly immunogenic and induced high magnitude, broad and polyfunctional CD4+ and CD8+ T cells (Harari et al., 2012). Similar to MVA, NYVAC elicits greater immune responses when used in prime-boost combinations rather than on its own (Harari et al., 2008; McCormack et al., 2008). In these EuroVacc studies, priming with DNAC followed with NYVAC-C boost elicited broad, polyfunctional and durable CD4+ $\mathrm{T}$ cell responses in greater than $90 \%$ of volunteers, compared to only $40 \%$ when NYVAC was used alone (Harari et al., 2008). Moreover, in a preclinical study with a DNA prime followed with NYVAC boost, responses to a vaccine expressing SIV-Gag/Pol/Env were boosted 10-fold with improved quality and quantity of $\mathrm{T}$ cell responses ( $\mathrm{Hel}$ et al., 2001). A NYVAC/SIV-gpe vaccine (expressing SIV Gag/Pol/Env) also elicited mucosal immune responses in macaques following both mucosal and systemic delivery (Stevceva et al., 2002).
Despite the skewing toward CD4+ $\mathrm{T}$ cell responses, NYVAC has potential to stimulate and boost more balanced immune responses when combined with other vectors, and its potential should be fully explored, especially for therapeutic HIV vaccines which require re-invigoration of $\mathrm{CD} 4+\mathrm{T}$ cell functions (and frequencies).

\section{CANARYPOX (ALVAC) VACCINE VECTORS}

ALVAC is an attenuated derivative of the canarypox virus that was repeatedly passaged in chick embryo fibroblasts and thus has restricted tropism with very minimal pathogenicity in humans (Yu et al., 2006). Despite the comparatively lower immunogenicity with respect to other poxvirus vectors such as MVA (Zhang et al., 2007) and NYVAC, the fact that ALVAC has no potential pre-existing immunity in humans makes it a more attractive HIV vaccine delivery vector. The ALVAC vector (vCP205) was shown to be safe and to induce strong CD8+ CTL and antibody responses to an HIV vaccine expressing gp120/41 and Gag/Pol sequences [ALVAC-HIV(vCP205)] in a Phase 1 clinical trial in the USA in the $1990 \mathrm{~s}$ (Belshe et al., 1998). A related ALVAC-based vaccine expressing multiple HIV antigens comprising Gag, Env, Nef, Pol and Pro [ALVAC-HIV(vCP300)] also induced durable CTL responses in healthy volunteers (Evans et al., 1999). In preclinical studies, ALVAC expressing SIV Gag/Pol/Env protected against low-dose oral SIVmac251 challenge of neonate rhesus macaques in a study design aiming to mimic HIV transmission through breast milk (Van Rompay et al., 2005). More recently ALVAC-based HIV vaccines have been tested in both adults and infants, where they have shown modest immunogenicity (Kintu et al., 2013; Kaleebu et al., 2014) and in the RV144 trial of ALVAC prime [ALVAC-HIV(vCP1521)] and protein boost (AIDSVAX $\mathrm{B} / \mathrm{E}$ rgp120), the only HIV vaccine candidate to show efficacy (Rerks-Ngarm et al., 2009, 2013).

While it is unclear whether the modest success of RV144 was due to the immunostimulatory potential of canarypox virus vector or immunogenicity of the vaccine inserts, the fact that the immunogens in the RV144 trial vaccines are not significantly distinct from those used in other HIV vaccines in the field eliminates the "immunogen effect," thus leaving the vectors and delivery methods as possible explanations. But, as the AIDSVAX vaccine (recombinant gp120) showed no efficacy in earlier trials (VAX003 and VAX004), the success of RV144 points to the delivery vector (ALVAC) and possibly the benefits of a combined viral vector and protein immunization regimen as opposed to homologous boosts. This might suggest that combined live vector-priming and protein-boost immunization modalities could be further refined to achieve greater potential for increased efficacy. Alternatively, protection by the combined vaccines could be attributed to $\mathrm{T}$ cell help for the antibody responses. It must however be noted that unlike the RV144 study, VAX003, and VAX004 were conducted in high-risk populations, which might be a strong confounding factor, although this might as well be reflective of the very limited efficacy of stand-alone protein subunit vaccines for HIV. Despite the modest efficacy of RV144, the immune responses waned within a short time indicating that ALVAC may not be a particularly suitable vector to induce long-lived anti-HIV immunity, unless it is combined with other powerful vectors. In 
direct comparison of immunogenicity, ALVAC was found to be less immunogenic than MVA, possibly due to MVA's enhanced antigen expression within dendritic cells (Zhang et al., 2007). Nonetheless, ALVAC is still quite promising for HIV vaccine delivery, as it is also already licensed for delivery of several veterinary vaccines including the feline leukemia virus (FeLV) and feline rabies vaccine (PUREVAX) and RECOMBITEK vaccine which protects against canine distemper, equine influenza and West Nile Virus.

\section{MYCOBACTERIUM BOVIS BACILLUS CALMETTE-GUERIN (BCG) VACCINE VECTORS}

Prevention of breast milk transmission of $\mathrm{HIV}-1$ remains an important goal for HIV vaccine researchers. BCG is an attenuated vaccine proven to be safe and has for many years been administered to new-born babies to immunize against Mycobacterium tuberculosis (Mtb). As such, BCG provides a platform to codeliver HIV immunogens in neonates to potentially protect against mother-to-child transmission of HIV-1. The potential use of BCG as an HIV vaccine vector was explored in preclinical studies of adult and new-born BALB/c mice using the HIV-1 clade A Gag immunogen (HIVA) (Mwau et al., 2004). Priming with recombinant BCG expressing HIVA (BCG.HIVA) induced HIVspecific T cell responses which were efficiently boosted with rMVA (MVA.HIVA) (Hopkins et al., 2011a,b; Saubi et al., 2011, 2012). In further related studies, priming with BCG.HIVA and boosting with a combination vaccine expressing HIVA and the Mtb antigen 85A (mMVA.HIVA.85A) induced robust IFN- $\gamma$-producing $\mathrm{T}$ cells to both HIV-1 and Mtb antigens. Moreover, in adult mice, BCG.HIVA primed weak HIV-1-specific CD8+ T cell responses, which were strongly boosted with either Ad5 (HAdV5.HIVA) or rMVA (MVA.HIVA). Thus, immunization of neonates with recombinant BCG expressing HIV-1 immunogens, followed with an MVA boost expressing the same HIV immunogen might concurrently protect against Mtb and HIV-1. It remains to be seen how these rBCG-vectored HIV-1 vaccines will perform in clinical studies.

\section{REPLICATION-COMPETENT VIRAL VECTORS}

The unprecedented success of the SIVmac239 $\Delta$ nef experimental vaccine in rhesus macaques (Reynolds et al., 2008, 2010) gives a hint that possibly, a successful HIV vaccine will require a live delivery vector, as these are known to induce high magnitude, durable and broadly effective immunity. But as exciting as this may sound, there are significant challenges in terms of balancing the safety and immunogenicity vs. replicative capacity. Of the adenoviruses, Ad4 and Ad7 have been tested in clinical studies (by oral delivery) and were successfully used for the prevention of respiratory and enteric illnesses (Hoke and Snyder, 2013). These replication competent adenoviruses naturally infect and replicate in mucosal tissues (Patterson and Robert-Guroff, 2008) and could thus be quite relevant for HIV vaccines. Preclinical studies of recombinant Ad4 expressing HIV1 clade C envelope gp160 (Ad4Env160), gp140 (Ad4Env140), and gp120 (Ad4Env120) demonstrated induction of envelope-specific $\mathrm{T}$ cells in mice and antibody responses in rabbits (Alexander et al., 2013). Serum from the rabbits was able to neutralize a tier
1 clade $\mathrm{C}$ pseudovirus and to a lesser extent, homologous and heterologous tier 2 pseudoviruses.

A replicating CMV vectored SIV vaccine (RhCMV-SIV/Gag, Rev/Nef/Tat, Pol, Env) was shown to persist in vaccinated rhesus macaques and conferred durable protection from disease progression owing to induction of high magnitude effector memory CD8+ T cells, despite pre-existing CMV immunity (Hansen et al., 2009, 2011, 2013). Other replication-competent viruses in clinical development include the TianTan vaccinia virus (TT), Vesicular stomatitis virus (VSV), a derivative of NYVAC (NYVAC-C-KC) and Sendai virus $(\mathrm{SeV})$. The TianTan vaccinia virus was used in a DNA-prime (pCCMp24)/Tiantan boost (rddVTT-CCMp24) regimen where it was shown to induce antibody and HIV-specific T cell responses (including memory phenotypes) following intramuscular delivery and has now been advanced to Phase II clinical study in China (Excler et al., 2010; Liu et al., 2013). The NYVAC$\mathrm{C}-\mathrm{KC}$ vectors have shown superior cellular and humoral immunity compared to the non-replicating NYVAC, at least in mice (Kibler et al., 2011; Gomez et al., 2012).

A Sendai virus vector expressing SIV Gag (SeV-Gag) administered intranasally as a boost following intramuscular priming with an envelope-independent DNA vaccine (CMV-SHIVdEN) demonstrated very strong suppression of intravenous SIVmac239 challenge in rhesus macaques, which was extended over a 3year period (Matano et al., 2001; Takeda et al., 2003; Kawada et al., 2007). Clinical investigations of a SeV-based candidate HIV vaccine expressing Gag [SeV-G (NP)] are ongoing in Rwanda, Kenya and the UK, and it is expected that results of these trials will provide a feel of the potential of Sendai virus as an HIV vaccine vector. Attenuated VSV is a non-pathogenic, low sero-prevalence vector that was also found to be quite promising as it achieved virus control during SHIV89.6P challenge experiments in rhesus macaques immunized with rVSV expressing Gag and Env (Rose et al., 2001). Recombinant VSV vector was shown to induce strong memory CTL responses to HIV$1 \mathrm{Gag}$ and Env in mice, which were significantly amplified by boosting with heterologous recombinant vaccinia virus vectors (Haglund et al., 2002). It is postulated that intranasal delivery of rVSV vaccines in combination with IL-12 administered during DNA priming may elicit mucosal immunity for HIV (Egan et al., 2004, 2005). Priming with rVSV-Gag/Pol/Env (VSV-SIVgpe) followed with MVA-Gag/Pol/Env (MVA-SIVgpe) boost was shown to induce strong and long-lived antibody and cellular responses that achieved long-term control of SHIV replication (Schell et al., 2009; Van Rompay et al., 2010). An ongoing phase 1 trial of rVSV-HIV-1 Gag vaccine (HVTN090) has demonstrated clinical safety and $\mathrm{T}$ cell immunogenicity following intramuscular delivery (Fuchs et al., 2012, 2013), although the magnitude of responses was limited and will most likely require priming (or boosting) with suitable vectors.

Other vectors being explored include rhadinovirus (Bilello et al., 2011), yellow fever virus (Bonaldo et al., 2010), rabies virus (Faul et al., 2009), Venezuelan equine encephalitis virus (VEEV) (Caley et al., 1997) and Semliki Forrest virus (Schell et al., 2011), all of which have shown strong immunogenicity, with some achieving efficacy in NHP challenge protection models. Influenza virus vaccine vectors have also been 
studied extensively and have been successfully used as delivery vehicles for several experimental HIV vaccines (Li et al., 1993a, 2013; Muster et al., 1994, 1995; Garcia-Sastre and Palese, 1995; Palese et al., 1997; Sexton et al., 2009). As natural mucosal pathogens, influenza virus vectors are well-adapted for stimulating robust mucosal and systemic immunity comprising both antibody and cellular immune responses (Garcia-Sastre and Palese, 1995; Palese et al., 1997; Li et al., 2013). Mucosal immunization of mice with chimeric influenza virus vectors expressing the HIV-1 gp120 V3 loop peptide (IHIGPGRAFTYTT) (Li et al., 1993a) or the gp41 epitope (ELDKWA) (Muster et al., 1993, 1994, 1995) was shown to induce persistent antibody and CTL responses. Influenza virus vectors might be successfully combined in prime-boost regimens as demonstrated in influenza virus-prime and MVA-boost studies in mice (Gherardi et al., 2003), although they have a limited capacity for immunogen insertion.

\section{HETEROLOGOUS PRIME-BOOST STRATEGIES FOR ENHANCED HIV VACCINE EFFICACY}

Repeated vaccination in heterologous prime boost approaches employing different vector combinations in a specific order is widely accepted as the most efficient means to induce superior quality and quantity of vaccine-specific immune responses (Li et al., 1993b; Ramshaw and Ramsay, 2000; Estcourt et al., 2002; McShane, 2002; Newman, 2002). Heterologous prime boost regimes allow immune boosting without creating problems of anti-vector immunity. Furthermore, heterologous prime-boosts result in increased frequencies of memory $\mathrm{T}$ cells, and it has been shown that the number of immunizations can significantly influence the phenotype of vaccine-specific memory $\mathrm{T}$ cells, with secondary and tertiary immunizations generating effector-like memory $\mathrm{T}$ cells which preferentially accumulate in non-lymphoid organs (Masopust et al., 2006; Nolz and Harty, 2011). These findings have huge implications on the quality and potential of mucosal surveillance of cells induced in prime-boost vaccination protocols.

Distinct live viral vectors can be combined in prime-boost regimes to maximize immune responses. In most studies DNA has been used for priming, but recently a number of virus vectors including Adenoviruses, influenza viruses as well as fowlpox and canarypox have been tested in prime-boost regimens. Prime-boost regimens comprising Adenovirus and MVA or heterologous Adenovirus strains have recently been shown to induce both cellular and humoral immune responses to SIV and malaria antigens (Draper et al., 2008; Liu et al., 2009; Tatsis et al., 2009; Barouch et al., 2012). In particular, impressive protection against SIV acquisition in rhesus monkeys was achieved following immunization with a SIV $S M E 543-\mathrm{Gag} / \mathrm{Pol} / \mathrm{Env}$ vaccine delivered by Ad26/MVA and Ad35/Ad26 prime-boost regimens which induced a mixture of neutralizing and binding antibody as well as cellular immune responses (Barouch et al., 2012). This study further demonstrated induction of both systemic and mucosal immune responses and achieved protection from both acquisition and disease progression, thus providing proof of concept that HIV-1 acquisition and post-infection control might be achieved by improved immunogen design and delivery strategies. Heterologous or homologous regimens comprising DNA/MVA, MVA/Ad26, and MVA/MVA were comparatively less efficacious than Ad26/MVA or Ad35/Ad26, which reduced viral load set-points by greater than 100-fold. A Phase 1 clinical trial (B003/IPCAVD-004) assessing the immunogenicity of various prime-boost combinations of Ad26 and Ad35 is ongoing, and will inform the field on the clinical utility of these two promising human adenovirus vector combinations. Another NHP study employing three doses of plasmid DNA followed with Ad5 to deliver various immunogens comprising

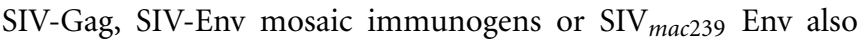
induced cellular and antibody responses (neutralizing antibodies and ADCC) and achieved significant protection against intrarectal challenge of rhesus macaques with $\operatorname{SIV}_{s m E 660}$ that was a mismatch of the vaccine strain (Roederer et al., 2014). Moreover, superior immunogenicity of prime-boost combinations using DNA/ChAdV63/MVA or ChAdV63/MVA has been demonstrated in a Phase I study (Borthwick et al., 2014).

The success of a viral vector for priming has already been demonstrated in the RV144 study which used ALVAC to prime antibody and $\mathrm{T}$ cell responses, followed with a protein boost (Rerks-Ngarm et al., 2009). Although priming with DNA has always seemed a better strategy as it focuses the immune response to the immunogen transgene, as opposed to viral vectors which carry multitudes of immunogenic antigens within their backbones, the efficacy of viral-vector priming followed by protein boosting in the RV144 study and the superior immunogenicity of virus-prime/virus-boost in the studies discussed above support the use of viral vectors for both priming and boosting. Therefore, heterologous prime-boost regimens combining DNA, Adenovirus and MVA or ALVAC are likely to achieve efficacy against HIV in clinical trials, although this will require that HIV Env or genes encoding NAb epitopes are included in the immunogen formulations (Barouch et al., 2012, 2013). Preclinical studies investigating the potential of combined chimpanzee adenovirus, MVA and protein prime-boost regimens to deliver immunogens which can stimulate broadly neutralizing antibodies such as BG505 are underway. The success of recombinant adenovirus vector priming followed with MVA boost in inducing high-titre antibodies either on their own or in conjunction with molecular adjuvants has already been proven in preclinical studies of malaria (Draper et al., 2008). Possibly the persistence of adenovirus ensures continuous antigen supply which is suitable for $B$ cell priming. It is envisaged that optimal delivery modalities which combine HIV immunogens eliciting BNAbs with those that stimulate strong $\mathrm{T}$ cell immunity will achieve enhanced vaccine efficacy. Of course a major caveat of combining strong $\mathrm{T}$ cell vectors with antibody-producing immunogens is the possible immune interference of antibody production by these vectors. Nevertheless, this can be optimized perhaps by employing several protein boosts with powerful adjuvants in order to deliver the most balanced immune responses.

\section{POTENTIAL VACCINE-ASSOCIATED RISK OF HIV ACOUISITION}

The increased risk of HIV-1 acquisition in the STEP and HVTN505 trial vaccinees despite strong immune responses has 
raised many unanswered questions as to whether the vaccine delivery modalities, suboptimal potency of the HIV immunogens or other unknown external factors are responsible for vaccine failure. As far as immunogen design, the vaccine construct used in the STEP, Phambili and HVTN505 studies represents one of the most comprehensive immunogens with broad coverage, as it comprised a 6-plasmid DNA and rAd5 vectors expressing $\mathrm{Gag} / \mathrm{Pol} / \mathrm{Nef} / \mathrm{Env}$ proteins from multiple clades. Other immunogens based on similar or far less comprehensive HIV protein coverage have also been tested and showed varied degrees of immunogenicity. Thus, an understanding on whether the outcomes of the STEP/Phambili/HVTN505 studies (efficacy, immunogenicity or increased risk of acquisition) would have been different if other delivery vectors (such as DNA/MVA, DNA/ALVAC or DNA/Ad35/Ad26 or even a replicating CMV vector) had been used to deliver the same immunogens in these trials is key for further progression in the field. An Alternative way to look at this is to ask whether the results of RV144 trial would have been worse if Ad5 was used instead of ALVAC, assuming that the prevalence of Ad5 neutralizing antibodies in the RV144 population does not differ significantly from the STEP and Phambili study populations.

The finding that the vaccine was not at all efficacious amongst men who were circumcised or in uncircumcised men who did not have pre-existing Ad5 immunity raises doubts as to whether efficacy was genuinely hindered by Ad5 serostatus. This is further supported by the results of HVTN505 study which tested only circumcised individuals without Ad5 antibodies, yet no protection was observed. Moreover, the absence of Ad5 antibodies in the HVTN505 study participants (which should in theory allow for higher immunogenicity) was not associated with any significant enhancement of the magnitude and quality of immune responses over those seen in the STEP and Phambili studies. Therefore, Ad5 serostatus can be safely removed from the equation, leaving the only plausible explanation for vaccine failure to be the quality and quantity of immune responses. If this can be fully documented beyond doubt then it implies that either the Ad5 delivery vector or the HIV-1 antigens used were not immunogenic enough to afford protection from infection or post-infection virus control. However, considering that Ad5 is one of the most immunogenic vectors currently available, (and that the immunogen used in these studies was comprehensive and well-designed), this would have serious implications for vaccine design, as it sets the bar really high for new candidate vaccines which would be expected to stimulate responses of extremely higher magnitudes and superior qualitative properties in order to achieve even the minimal efficacy. On a brighter side, this would perhaps instigate intense scrutiny of the current methods used for assessing vaccine immunogenicity in order to standardize and synchronize with those for efficacy measurements.

One other interesting question is whether (and how) Ad5 sero-positivity is intrinsically associated with HIV acquisition. Although studies of uncircumcised men document increased risk of natural HIV acquisition due to a high frequency of CD4+CCR5+ target cells in the foreskin (Prodger et al., 2012), how this relates their Ad5 sero-positivity and titre levels with infection risk is not very clear. However, the fact that the risk of HIV-1 acquisition in the STEP study diminished with time after immunization, and eventually leveled up with placebo recipients (Buchbinder et al., 2008) might in actual fact support a role for vaccine-induced immune activation in HIV acquisition (Tenbusch et al., 2012). Perhaps this could be as a result of generalized immune activation or induction of activated vaccinespecific HIV-1 targets with mucosal-homing properties. Should this be the case, then this would not be unique to Ad5 vectors alone and it would therefore be expected to equally affect other delivery vectors capable of inducing activated mucosal-homing target cells. However, as there were no notable differences in activated circulating $\mathrm{T}$ cells between vaccinees and placebos, it is unlikely that generalized vaccine-induced immune activation played a role, although it remains possible that there could have been significant differences in activated targets at mucosal sites which were not measured.

This then raises another interesting question as to whether the outcome of the STEP/Phambili/HVTN505 studies would have been significantly worse (or better) had the vaccines been administered mucosally. This question might have two sides to it, in the sense that mucosal delivery would probably have generated higher frequencies of activated HIV targets at the genital mucosae, hence increasing the potential of fuelling infection. On the other hand, induction of robust and polyfunctional effector immune responses at mucosal portals of HIV entry would probably have cleared the incoming HIV before infection became established. Although these questions have no clear cut answers and cannot be addressed retrospectively in the context of the clinical trials they relate to, they however highlight the extreme challenges in HIV vaccine delivery, and new studies designed to directly tackle these issues will be quite informative for future vaccine development research. Studies looking at whether the most promising delivery vectors (and the respective immunogens) can concurrently induce activated HIV-1 target cells that preferentially home to and persist in the genito-rectal and GALT mucosae, and whether or not such vaccine-induced cells become highly permissive to HIV infection will be of particular interest in efforts aimed at limiting the risk of vaccine-induced HIV-1 acquisition and accelerated disease progression.

\section{PERSPECTIVES AND CONCLUSION}

Ideally, vectors for HIV-1 vaccines should directly target antigen presenting cells (APCs) or other immune cells to induce long-lived, strong antibody and cellular responses that can broadly disseminate to systemic and mucosal compartments. The vaccine-specific $T$ cells in particular should be broad and contain activated effector, effector memory and central memory phenotypes in various proportions in order to achieve a proper balance between immediate virus clearance and sustained immune-surveillance for long-term protection, as demonstrated by the RhCMV-SIV vaccine which controlled and cleared pathogenic SIV infection (Hansen et al., 2009, 2011, 2013). Furthermore, vectors which can stimulate polyfunctional CD4+ and CD8+ T cells that act in concert with B cells to inhibit HIV replication through a variety of mechanisms would be more successful than those inducing only mono-functional $\mathrm{T}$ cells of either subset alone. 
Of particular relevance to protection from infection would be vaccine vectors associated with homing and long-term persistence of vaccine-induced immune responsive cells at the genito-rectal mucosae (Chanzu and Ondondo, 2014) as well as other mucosal sites serving as HIV reservoirs. This remains a very important priority in consideration of the significant rapid CD4+ $\mathrm{T}$ cell depletion in the intestinal mucosa despite successful HAART (Brenchley et al., 2004; Mehandru et al., 2004). Thus, vaccine vectors which naturally infect cells within mucosal inductive sites, especially the replication-competent viruses such as adenovirus and influenza virus vectors (Gherardi et al., 2003; Sexton et al., 2009) which can be administered mucosally to trigger mucosal immunity, would be more suited for HIV vaccine delivery. Alternatively, delivery of vaccines via routes which enhance mucosal immunity (Holmgren et al., 2003; Holmgren and Czerkinsky, 2005; Czerkinsky and Holmgren, 2012) or vectors possessing an inherent ability to induce mucosal immunity in addition to systemic immune responses following parenteral or mucosal vaccine delivery (Moser et al., 2007) may be employed. Virosome vectors for instance, possess intrinsic adjuvant properties and a unique ability to target antigen presenting cells, hence have been very successful at inducing protective mucosal immunity in SHIV challenge models (Moser et al., 2007; Bomsel et al., 2011; Leroux-Roels et al., 2013). Other vectors suitable for mucosal vaccine delivery include VEEV (Caley et al., 1997). In the absence of mucosal delivery vectors, new delivery technologies such as the "prime and pull" approach may be utilized in conjunction with systemic delivery methods to enhance mucosal homing and subsequent immunity (Azizi et al., 2010; Shin and Iwasaki, 2012; Tregoning et al., 2013). In this approach, specialized chemokines are administered in mucosal compartments following parenteral immunization in order to chemo-attract the activated vaccine-specific immune cells from the systemic compartments. Furthermore, use of mucosal adjuvants such as CTB and LT-B (Albu et al., 2003; Yuki and Kiyono, 2003), proinflammatory cytokines (IL-1 $\alpha$, IL-12, and IL-18) (Belyakov et al., 1998b; Bradney et al., 2002; Albu et al., 2003) or immunostimulatory CpG motifs (Horner et al., 2001; Dumais et al., 2002; Daftarian et al., 2003; Jiang et al., 2005) which target recruitment of immune cells to the mucosal sites would be useful. Co-delivery of vaccines with genes encoding CCL19 and CCL28 was also shown to enhance HIV-1-specific T and B cell responses in the systemic as well as mucosal compartments (Hu et al., 2013).

In consideration of both safety and immunogenicity goals as already discussed, and with particular emphasis on the pivotal role of CTL responses in controlling HIV replication, it seems that non-replicating viral vectors with lower sero-prevalence would be highly desirable, mainly due to excellent safety profiles and potent adjuvant effect allowing for induction of very strong, high quality and long-lived cellular and humoral immunity. However, although safety and reduced immune interference would be guaranteed, a major caveat would be that these lower sero-prevalence vectors may not be adequately immunogenic. Perhaps these vectors can be re-engineered to improve their immunogenic potential. For instance, the immunogenicity of vectors such as MVA and NYVAC can be improved by removal of genes associated with immune evasion which counteract immune responses to the vaccine (Kibler et al., 2011; Gomez et al., 2012; Garcia-Arriaza et al., 2013). In other cases, addition of cytokine-encoding genes such as type 1 interferons, IL-12 or GM-CSF can enhance vaccine efficacy (Gherardi et al., 1999, 2000; Rodriguez et al., 1999; Ramshaw and Ramsay, 2000; Bayer et al., 2011). Furthermore, chemokines such as CCL3 which recruits professional APCs can be co-delivered with HIV antigens to enhance vaccine immunogenicity (Lietz et al., 2012).

Alternatively, vectors capable of inducing substantial immunogenicity in the presence of pre-existing natural or vaccine-induced anti-vector immunity may be worth considering, although it is expected that finding highly attenuated vectors which are safe and remain immunologically potent will be equally challenging. As discussed earlier, combining some of the most promising vectors in heterologous prime-boost regimens will significantly enhance the quantity, quality and protective efficacy of immune responses. However, in consideration of the possible catastrophic effects of elevated immune activation likely to arise from various vector combinations, it would be expected that suitable HIV vaccine vectors maintain lower levels of immune activation to limit the numbers of activated HIV-1 targets (Perreau et al., 2008; Benlahrech et al., 2009) likely to fuel infection in the event of exposure. Furthermore, it is documented that in the absence of a very strong protective immune responses to counteract the incoming virus, the presence of vaccine-specific $T$ cells which are activated and hence more susceptible to infection may increase the risk of acquisition (Tenbusch et al., 2012). Whether it is possible to achieve potent immunostimulatory capacity but with minimal immune activation still remains a subject of intense investigation.

When safety and versatility are considered, and in full view of the enormous technology advancements in DNA plasmid formulations and delivery, in conjunction with other immunomodulatory interventions such as SAP depletion and use of molecular adjuvants, recombinant DNA vaccines remain very attractive, although efforts to improve stimulation of long-lived effector/memory CD8+ T cell phenotypes are still needed to achieve long-term efficacy. Undoubtedly, repeated immunizations or combining DNA vaccines with persistent (replicating) vectors or vectors with slow immunogen release features would induce durable immunity. Nonetheless, replicating vectors with lower sero-prevalence and minimal pathogenicity (Rose et al., 2001; Kawada et al., 2007; Fuchs et al., 2013; Liu et al., 2013) are being considered as they would provide a persistent pool of HIV vaccine-specific effector memory phenotype cytotoxic T cells which are critical for long-term protection from disease progression (Hansen et al., 2009, 2011, 2013). Such effector memory responses would otherwise be expected to wane with time, in the absence of antigen. Replicating vectors may also be better-suited for induction of broadly neutralizing antibodies since persisting expression of the Env antigens is likely to drive high levels of somatic mutations required for affinity maturation of these antibodies (van Gils and Sanders, 2013). A new strategy that has been proven to induce durable and protective antibody responses in humanized mice challenged with high doses of diverse HIV strains is vectored immunoprophylaxis, which involves insertion of immunoglobulin genes into viral vectors such as the 
adeno-associated virus (AAV) to provide long-term expression of neutralizing antibodies (Balazs et al., 2012, 2014). Moreover, inclusion of Th2 cytokines such as IL-4, IL-5, and IL-6 which enhance B cell maturation into long-lived antibody secreting cells is yet another strategy already shown to induce high titres of neutralizing antibodies which protected mice from Friend Virus (Ohs et al., 2013). Other possible strategies include use of lentiviral vectors expressing $\mathrm{B}$ cell receptor genes encoding neutralizing antibodies to HIV-1 to transduce haematopoietic stem cells (Luo et al., 2009).

Since optimum induction of immune responses to vaccines strongly depends on innate immune triggering as well as the levels of transgene expression, vectors with natural adjuvant properties and therefore capable of strongly inducing innate immunity are particularly immunogenic and thus highly desirable. However, care must be taken to balance between strong innate function stimulation and the potential risk of inducing potent stimulation of immuno-pathological effects, including immune hyper-activation.

In conclusion, a successful vaccine for HIV will have to stimulate potent antibody and CTL responses broad enough to cover multiple HIV variants and with potential to neutralize, bind or suppress HIV-1 replication for sustained (possibly infinite) lengths of time. Of utmost importance, however is generation of vaccine-specific immune responses in the genito-rectal mucosae, the major portals of HIV entry. Emerging evidence strongly suggests that non-pathogenic, low-level replicating viral vectors which can mimic live attenuated vaccines, but with low seroprevalence might be the best way to achieve HIV vaccine efficacy. As these vectors persist long after immunization, they are capable of inducing and maintaining effector/memory CTLs for continued immune surveillance that is necessary to protect from infection, disease progression and to clear or prevent establishment of latent reservoirs. Thus, to achieve protective efficacy HIV vaccine development will need ingenious state of the art technologies to create the very best of $\mathrm{T}$ cell and antibody immunogens, delivered by the most potent but safe vectors possessing remarkably high capacity to induce both systemic and mucosal immunity, but without significant immune activation likely to fuel HIV acquisition. Recent significant advances in vaccine delivery technologies and HIV immunogen design provide hope that this is not far from reality.

\section{ACKNOWLEDGMENTS}

Beatrice O. Ondondo is a senior HIV vaccine development immunologist employed on a research grant supported by MRC UK.

\section{REFERENCES}

Abbink, P., Lemckert, A. A., Ewald, B. A., Lynch, D. M., Denholtz, M., Smits, S., et al. (2007). Comparative seroprevalence and immunogenicity of six rare serotype recombinant adenovirus vaccine vectors from subgroups B and D. J. Virol. 81, 4654-4663. doi: 10.1128/JVI.02696-06

Abe, S., Okuda, K., Ura, T., Kondo, A., Yoshida, A., Yoshizaki, S., et al. (2009). Adenovirus type 5 with modified hexons induces robust transgene-specific immune responses in mice with pre-existing immunity against adenovirus type 5. J. Gene Med. 11, 570-579. doi: 10.1002/jgm.1332

Afolabi, M. O., Ndure, J., Drammeh, A., Darboe, F., Mehedi, S. R., RowlandJones, S. L., et al. (2013). A phase I randomized clinical trial of candidate human immunodeficiency virus type 1 vaccine MVA.HIVA administered to Gambian infants. PLoS ONE 8:e78289. doi: 10.1371/journal.pone.00 78289

Albarran, Y. C. A., de la Garza, A., Cruz Quiroz, B. J., Vazquez Zea, E., Diaz Estrada, I., Mendez Fuentez, E., et al. (2007). MVA E2 recombinant vaccine in the treatment of human papillomavirus infection in men presenting intraurethral flat condyloma: a phase I/II study. BioDrugs 21, 47-59. doi: 10.2165/00063030200721010-00006

Albu, D. I., Jones-Trower, A., Woron, A. M., Stellrecht, K., Broder, C. C., and Metzger, D. W. (2003). Intranasal vaccination using interleukin-12 and cholera toxin subunit B as adjuvants to enhance mucosal and systemic immunity to human immunodeficiency virus type 1 glycoproteins. J. Virol. 77, 5589-5597. doi: 10.1128/JVI.77.10.5589-5597.2003

Alexander, J., Mendy, J., Vang, L., Avanzini, J. B., Garduno, F., Manayani, D. J., et al. (2013). Pre-clinical development of a recombinant, replication-competent adenovirus serotype 4 vector vaccine expressing HIV-1 envelope 1086 clade C. PLoS ONE 8:e82380. doi: 10.1371/journal.pone.0082380

Anderson, R. J., Hannan, C. M., Gilbert, S. C., Laidlaw, S. M., Sheu, E. G., Korten, S., et al. (2004). Enhanced CD8+ T cell immune responses and protection elicited against Plasmodium berghei malaria by prime boost immunization regimens using a novel attenuated fowlpox virus. J. Immunol. 172, 3094-3100. doi: 10.4049/jimmunol.172.5.3094

Antoine, G., Scheiflinger, F., Dorner, F., and Falkner, F. G. (1998). The complete genomic sequence of the modified vaccinia Ankara strain: comparison with other orthopoxviruses. Virology 244, 365-396. doi: 10.1006/viro.1998.9123

Appledorn, D. M., Patial, S., McBride, A., Godbehere, S., Van Rooijen, N., Parameswaran, N., et al. (2008). Adenovirus vector-induced innate inflammatory mediators, MAPK signaling, as well as adaptive immune responses are dependent upon both TLR2 and TLR9 in vivo. J. Immunol. 181, 2134-2144. doi: 10.4049/jimmunol.181.3.2134

Applequist, S. E., Rollman, E., Wareing, M. D., Liden, M., Rozell, B., Hinkula, J., et al. (2005). Activation of innate immunity, inflammation, and potentiation of DNA vaccination through mammalian expression of the TLR5 agonist flagellin. J. Immunol. 175, 3882-3891. doi: 10.4049/jimmunol.175.6.3882

Azizi, A., Ghunaim, H., Diaz-Mitoma, F., and Mestecky, J. (2010). Mucosal HIV vaccines: a holy grail or a dud? Vaccine 28, 4015-4026. doi: 10.1016/j.vaccine.2010.04.018

Baden, L. R., Walsh, S. R., Seaman, M. S., Tucker, R. P., Krause, K. H., Patel, A., et al. (2013). First-in-human evaluation of the safety and immunogenicity of a recombinant adenovirus serotype 26 HIV-1 Env vaccine (IPCAVD 001). J. Infect. Dis. 207, 240-247. doi: 10.1093/infdis/jis670

Bakari, M., Aboud, S., Nilsson, C., Francis, J., Buma, D., Moshiro, C., et al. (2011). Broad and potent immune responses to a low dose intradermal HIV-1 DNA boosted with HIV-1 recombinant MVA among healthy adults in Tanzania. Vaccine 29, 8417-8428. doi: 10.1016/j.vaccine.2011.08.001

Balazs, A. B., Chen, J., Hong, C. M., Rao, D. S., Yang, L., and Baltimore, D. (2012). Antibody-based protection against HIV infection by vectored immunoprophylaxis. Nature 481, 81-84. doi: 10.1038/nature10660

Balazs, A. B., Ouyang, Y., Hong, C. M., Chen, J., Nguyen, S. M., Rao, D. S., et al. (2014). Vectored immunoprophylaxis protects humanized mice from mucosal HIV transmission. Nat. Med. 20, 296-300. doi: 10.1038/nm.3471

Bangari, D. S., and Mittal, S. K. (2006). Development of nonhuman adenoviruses as vaccine vectors. Vaccine 24, 849-862. doi: 10.1016/j.vaccine.2005.08.101

Bansal, A., Jackson, B., West, K., Wang, S., Lu, S., Kennedy, J. S., et al. (2008). Multifunctional T-cell characteristics induced by a polyvalent DNA prime/protein boost human immunodeficiency virus type 1 vaccine regimen given to healthy adults are dependent on the route and dose of administration. J. Virol. 82, 6458-6469. doi: 10.1128/JVI.00068-08

Barnes, E., Folgori, A., Capone, S., Swadling, L., Aston, S., Kurioka, A., et al. (2012). Novel adenovirus-based vaccines induce broad and sustained $\mathrm{T}$ cell responses to HCV in man. Sci. Transl. Med. 4, 115ral. doi: 10.1126/scitranslmed.3003155

Barouch, D. H., Kik, S. V., Weverling, G. J., Dilan, R., King, S. L., Maxfield, L. F., et al. (2011). International seroepidemiology of adenovirus serotypes 5, 26, 35 , and 48 in pediatric and adult populations. Vaccine 29, 5203-5209. doi: 10.1016/j.vaccine.2011.05.025

Barouch, D. H., Liu, J., Li, H., Maxfield, L. F., Abbink, P., Lynch, D. M., et al. (2012). Vaccine protection against acquisition of neutralization-resistant SIV challenges in rhesus monkeys. Nature 482, 89-93. doi: 10.1038/nature10766

Barouch, D. H., Liu, J., Peter, L., Abbink, P., Iampietro, M. J., Cheung, A., et al. (2013). Characterization of humoral and cellular immune responses elicited 
by a recombinant adenovirus serotype $26 \mathrm{HIV}-1$ Env vaccine in healthy adults (IPCAVD 001). J. Infect. Dis. 207, 248-256. doi: 10.1093/infdis/jis671

Barouch, D. H., O’Brien, K. L., Simmons, N. L., King, S. L., Abbink, P., Maxfield, L. F., et al. (2010). Mosaic HIV-1 vaccines expand the breadth and depth of cellular immune responses in rhesus monkeys. Nat. Med. 16, 319-323. doi: 10.1038/nm.2089

Bassett, J. D., Swift, S. L., and Bramson, J. L. (2011). Optimizing vaccine-induced CD8(+) T-cell immunity: focus on recombinant adenovirus vectors. Expert Rev. Vaccines 10, 1307-1319. doi: 10.1586/erv.11.88

Bayer, W., Lietz, R., Ontikatze, T., Johrden, L., Tenbusch, M., Nabi, G., et al. (2011). Improved vaccine protection against retrovirus infection after co-administration of adenoviral vectors encoding viral antigens and type I interferon subtypes. Retrovirology 8:75. doi: 10.1186/1742-46 90-8-75

Bejon, P., Ogada, E., Mwangi, T., Milligan, P., Lang, T., Fegan, G., et al. (2007). Extended follow-up following a phase $2 \mathrm{~b}$ randomized trial of the candidate malaria vaccines FP9 ME-TRAP and MVA ME-TRAP among children in Kenya. PLoS ONE 2:e707. doi: 10.1371/journal.pone.0000707

Belshe, R. B., Gorse, G. J., Mulligan, M. J., Evans, T. G., Keefer, M. C., Excler, J. L., et al. (1998). Induction of immune responses to HIV-1 by canarypox virus (ALVAC) HIV-1 and gp120 SF-2 recombinant vaccines in uninfected volunteers. NIAID AIDS Vaccine Evaluation Group. AIDS 12, 2407-2415.

Belyakov, I. M., Ahlers, J. D., Brandwein, B. Y., Earl, P., Kelsall, B. L., Moss, B., et al. (1998b). The importance of local mucosal HIV-specific CD8(+) cytotoxic $\mathrm{T}$ lymphocytes for resistance to mucosal viral transmission in mice and enhancement of resistance by local administration of IL-12. J. Clin. Invest. 102, 2072-2081. doi: 10.1172/JCI5102

Belyakov, I. M., Derby, M. A., Ahlers, J. D., Kelsall, B. L., Earl, P., Moss, B., et al. (1998a). Mucosal immunization with HIV-1 peptide vaccine induces mucosal and systemic cytotoxic $\mathrm{T}$ lymphocytes and protective immunity in mice against intrarectal recombinant HIV-vaccinia challenge. Proc. Natl. Acad. Sci. U.S.A. 95, 1709-1714.

Benlahrech, A., Harris, J., Meiser, A., Papagatsias, T., Hornig, J., Hayes, P., et al. (2009). Adenovirus vector vaccination induces expansion of memory CD4 T cells with a mucosal homing phenotype that are readily susceptible to HIV1. Proc. Natl. Acad. Sci. U.S.A. 106, 19940-19945. doi: 10.1073/pnas.09078 98106

Bergelson, J. M., Cunningham, J. A., Droguett, G., Kurt-Jones, E. A., Krithivas, A., Hong, J. S., et al. (1997). Isolation of a common receptor for Coxsackie B viruses and adenoviruses 2 and 5. Science 275, 1320-1323.

Bergman, P. J., McKnight, J., Novosad, A., Charney, S., Farrelly, J., Craft, D., et al. (2003). Long-term survival of dogs with advanced malignant melanoma after DNA vaccination with xenogeneic human tyrosinase: a phase I trial. Clin. Cancer Res. 9, 1284-1290.

Berthoud, T. K., Hamill, M., Lillie, P. J., Hwenda, L., Collins, K. A., Ewer, K. J., et al. (2011). Potent CD8+ T-cell immunogenicity in humans of a novel heterosubtypic influenza A vaccine, MVA-NP+M1. Clin. Infect. Dis. 52, 1-7. doi: 10.1093/cid/ciq015

Bertley, F. M., Kozlowski, P. A., Wang, S. W., Chappelle, J., Patel, J., Sonuyi, O., et al. (2004). Control of simian/human immunodeficiency virus viremia and disease progression after IL-2-augmented DNA-modified vaccinia virus Ankara nasal vaccination in nonhuman primates. J. Immunol. 172, 3745-3757. doi: 10.4049/jimmunol.172.6.3745

Bilello, J. P., Manrique, J. M., Shin, Y. C., Lauer, W., Li, W., Lifson, J. D., et al. (2011). Vaccine protection against simian immunodeficiency virus in monkeys using recombinant gamma-2 herpesvirus. J. Virol. 85, 12708-12720. doi: 10.1128/JVI.00865-11

Bodin, K., Ellmerich, S., Kahan, M. C., Tennent, G. A., Loesch, A., Gilbertson, J. A., et al. (2010). Antibodies to human serum amyloid P component eliminate visceral amyloid deposits. Nature 468, 93-97. doi: 10.1038/nature09494

Bomsel, M., Tudor, D., Drillet, A. S., Alfsen, A., Ganor, Y., Roger, M. G., et al. (2011). Immunization with HIV-1 gp41 subunit virosomes induces mucosal antibodies protecting nonhuman primates against vaginal SHIV challenges. Immunity 34 , 269-280. doi: 10.1016/j.immuni.2011.01.015

Bonaldo, M. C., Martins, M. A., Rudersdorf, R., Mudd, P. A., Sacha, J. B., Piaskowski, S. M., et al. (2010). Recombinant yellow fever vaccine virus 17D expressing simian immunodeficiency virus SIVmac239 gag induces SIV-specific CD8+ T-cell responses in rhesus macaques. J. Virol. 84, 3699-3706. doi: 10.1128/JVI.02255-09
Borthwick, N., Ahmed, T., Ondondo, B., Hayes, P., Rose, A., Ebrahimsa, U., et al. (2014). Vaccine-elicited human $\mathrm{T}$ cells recognizing conserved protein regions inhibit HIV-1. Mol. Ther. 22, 464-475. doi: 10.1038/mt.2013.248

Boyer, J. D., Robinson, T. M., Kutzler, M. A., Parkinson, R., Calarota, S. A. Sidhu, M. K., et al. (2005). SIV DNA vaccine co-administered with IL12 expression plasmid enhances CD8 SIV cellular immune responses in cynomolgus macaques. J. Med. Primatol. 34, 262-270. doi: 10.1111/j.16000684.2005.00124.x

Bradney, C. P., Sempowski, G. D., Liao, H. X., Haynes, B. F., and Staats, H. F. (2002). Cytokines as adjuvants for the induction of anti-human immunodeficiency virus peptide immunoglobulin $\mathrm{G}$ (IgG) and IgA antibodies in serum and mucosal secretions after nasal immunization. J. Virol. 76, 517-524. doi: 10.1128/JVI.76.2.517-524.2002

Brave, A., Gudmundsdotter, L., Sandstrom, E., Haller, B. K., Hallengard, D., Maltais, A. K., et al. (2010). Biodistribution, persistence and lack of integration of a multigene HIV vaccine delivered by needle-free intradermal injection and electroporation. Vaccine 28, 8203-8209. doi: 10.1016/j.vaccine.2010.08.108

Brenchley, J. M., Schacker, T. W., Ruff, L. E., Price, D. A., Taylor, J. H., Beilman, G. J., et al. (2004). CD4+ T cell depletion during all stages of HIV disease occurs predominantly in the gastrointestinal tract. J. Exp. Med. 200, 749-759. doi: $10.1084 / \mathrm{jem} .20040874$

Bruder, J. T., Chen, P., Semenova, E., Thomas, C. A., Konovalova, S., Ekberg, G., et al. (2013). Identification of a suppressor mutation that improves the yields of hexon-modified adenovirus vectors. J. Virol. 87, 9661-9671. doi: 10.1128/JVI.00462-13

Bruder, J. T., Semenova, E., Chen, P., Limbach, K., Patterson, N. B., Stefaniak, M. E., et al. (2012). Modification of Ad5 hexon hypervariable regions circumvents preexisting Ad5 neutralizing antibodies and induces protective immune responses. PLoS ONE 7:e33920. doi: 10.1371/journal.pone.0033920

Buchbinder, S. P., Mehrotra, D. V., Duerr, A., Fitzgerald, D. W., Mogg, R., Li, D., et al. (2008). Efficacy assessment of a cell-mediated immunity HIV-1 vaccine (the Step Study): a double-blind, randomised, placebo-controlled, testof-concept trial. Lancet 372, 1881-1893. doi: 10.1016/S0140-6736(08)61591-3

Caley, I. J., Betts, M. R., Irlbeck, D. M., Davis, N. L., Swanstrom, R., Frelinger, J. A., et al. (1997). Humoral, mucosal, and cellular immunity in response to a human immunodeficiency virus type 1 immunogen expressed by a Venezuelan equine encephalitis virus vaccine vector. J. Virol. 71, 3031-3038

Capone, S., Reyes-Sandoval, A., Naddeo, M., Siani, L., Ammendola, V., Rollier, C. S., et al. (2010). Immune responses against a liver-stage malaria antigen induced by simian adenoviral vector AdCh 63 and MVA prime-boost immunisation in non-human primates. Vaccine 29, 256-265. doi: 10.1016/j.vaccine.2010. 10.041

Carroll, M. W., and Moss, B. (1997). Host range and cytopathogenicity of the highly attenuated MVA strain of vaccinia virus: propagation and generation of recombinant viruses in a nonhuman mammalian cell line. Virology 238, 198-211. doi: 10.1006/viro.1997.8845

Casimiro, D. R., Bett, A. J., Fu, T. M., Davies, M. E., Tang, A., Wilson, K. A., et al. (2004). Heterologous human immunodeficiency virus type 1 priming-boosting immunization strategies involving replication-defective adenovirus and poxvirus vaccine vectors. J. Virol. 78, 11434-11438. doi: 10.1128/JVI.78.20.11434-11438.2004

Casimiro, D. R., Chen, L., Fu, T. M., Evans, R. K., Caulfield, M. J., Davies, M. E., et al. (2003a). Comparative immunogenicity in rhesus monkeys of DNA plasmid, recombinant vaccinia virus, and replication-defective adenovirus vectors expressing a human immunodeficiency virus type 1 gag gene. J. Virol. 77, 6305-6313. doi: 10.1128/JVI.77.11.6305-6313.2003

Casimiro, D. R., Tang, A., Chen, L., Fu, T. M., Evans, R. K., Davies, M. E., et al. (2003b). Vaccine-induced immunity in baboons by using DNA and replicationincompetent adenovirus type 5 vectors expressing a human immunodeficiency virus type 1 gag gene. J. Virol. 77, 7663-7668. doi: 10.1128/JVI.77.13.76637668.2003

Catanzaro, A. T., Koup, R. A., Roederer, M., Bailer, R. T., Enama, M. E., Moodie, Z., et al. (2006). Phase 1 safety and immunogenicity evaluation of a multiclade HIV-1 candidate vaccine delivered by a replication-defective recombinant adenovirus vector. J. Infect. Dis. 194, 1638-1649. doi: 10.1086/509258

Cerwenka, A., Morgan, T. M., and Dutton, R. W. (1999). Naive, effector, and memory CD8 $\mathrm{T}$ cells in protection against pulmonary influenza virus infection: homing properties rather than initial frequencies are crucial. J. Immunol. 163, 5535-5543. 
Chanzu, N., and Ondondo, B. (2014). Induction of potent and long-lived antibody and cellular immune responses in the genitorectal mucosa could be the critical determinant of HIV vaccine efficacy. Front. Immunol. 5:202. doi: 10.3389/fimmu.2014.00202

Chen, H., Xiang, Z. Q., Li, Y., Kurupati, R. K., Jia, B., Bian, A., et al. (2010). Adenovirus-based vaccines: comparison of vectors from three species of adenoviridae. J. Virol. 84, 10522-10532. doi: 10.1128/JVI.00450-10

Chong, S. Y., Egan, M. A., Kutzler, M. A., Megati, S., Masood, A., Roopchard, V., et al. (2007). Comparative ability of plasmid IL-12 and IL-15 to enhance cellular and humoral immune responses elicited by a SIVgag plasmid DNA vaccine and alter disease progression following $\operatorname{SHIV}(89.6 \mathrm{P})$ challenge in rhesus macaques. Vaccine 25, 4967-4982. doi: 10.1016/j.vaccine.2006.11.070

Chuang, I., Sedegah, M., Cicatelli, S., Spring, M., Polhemus, M., Tamminga, C., et al. (2013). DNA prime/Adenovirus boost malaria vaccine encoding P. falciparum CSP and AMA1 induces sterile protection associated with cell-mediated immunity. PLoS ONE 8:e55571. doi: 10.1371/journal.pone.0055571

Colloca, S., Barnes, E., Folgori, A., Ammendola, V., Capone, S., Cirillo, A., et al. (2012). Vaccine vectors derived from a large collection of simian adenoviruses induce potent cellular immunity across multiple species. Sci. Transl. Med. 4, 115ra2. doi: 10.1126/scitranslmed.3002925

Corona Gutierrez, C. M., Tinoco, A., Navarro, T., Contreras, M. L., Cortes, R. R., Calzado, P., et al. (2004). Therapeutic vaccination with MVA E2 can eliminate precancerous lesions (CIN 1, CIN 2, and CIN 3) associated with infection by oncogenic human papillomavirus. Hum. Gene Ther. 15, 421-431. doi: 10.1089/10430340460745757

Cristillo, A. D., Ferrari, M. G., Hudacik, L., Lewis, B., Galmin, L., Bowen, B., et al. (2011). Induction of mucosal and systemic antibody and T-cell responses following prime-boost immunization with novel adjuvanted human immunodeficiency virus-1-vaccine formulations. J. Gen. Virol. 92(Pt 1), 128-140. doi: 10.1099/vir.0.023242-0

Cristillo, A. D., Weiss, D., Hudacik, L., Restrepo, S., Galmin, L., Suschak, J., et al (2008). Persistent antibody and T cell responses induced by HIV-1 DNA vaccine delivered by electroporation. Biochem. Biophys. Res. Commun. 366, 29-35. doi: 10.1016/j.bbrc.2007.11.052

Czerkinsky, C., and Holmgren, J. (2012). Mucosal delivery routes for optimal immunization: targeting immunity to the right tissues. Curr. Top. Microbiol. Immunol. 354, 1-18. doi: 10.1007/82_2010_112

Daftarian, P., Ali, S., Sharan, R., Lacey, S. F., La Rosa, C., Longmate, J., et al. (2003). Immunization with Th-CTL fusion peptide and cytosine-phosphateguanine DNA in transgenic HLA-A2 mice induces recognition of HIV-infected $\mathrm{T}$ cells and clears vaccinia virus challenge. J. Immunol. 171, 4028-4039. doi: 10.4049/jimmunol.171.8.4028

Davis, B. S., Chang, G. J., Cropp, B., Roehrig, J. T., Martin, D. A., Mitchell, C. J., et al. (2001). West Nile virus recombinant DNA vaccine protects mouse and horse from virus challenge and expresses in vitro a noninfectious recombinant antigen that can be used in enzyme-linked immunosorbent assays. J. Virol. 75, 4040-4047. doi: 10.1128/JVI.75.9.4040-4047.2001

Dicks, M. D., Spencer, A. J., Edwards, N. J., Wadell, G., Bojang, K., Gilbert, S. C., et al. (2012). A novel chimpanzee adenovirus vector with low human seroprevalence: improved systems for vector derivation and comparative immunogenicity. PLoS ONE 7:e40385. doi: 10.1371/journal.pone.0040385

Dorrell, L., Yang, H., Ondondo, B., Dong, T., di Gleria, K., Suttill, A., et al. (2006). Expansion and diversification of virus-specific $\mathrm{T}$ cells following immunization of human immunodeficiency virus type 1 (HIV-1)-infected individuals with a recombinant modified vaccinia virus Ankara/HIV-1 Gag vaccine. J. Virol. 80 , 4705-4716. doi: 10.1128/JVI.80.10.4705-4716.2006

Drape, R. J., Macklin, M. D., Barr, L. J., Jones, S., Haynes, J. R., and Dean, H. J. (2006). Epidermal DNA vaccine for influenza is immunogenic in humans. Vaccine 24, 4475-4481. doi: 10.1016/j.vaccine.2005.08.012

Draper, S. J., Biswas, S., Spencer, A. J., Remarque, E. J., Capone, S., Naddeo, M., et al (2010). Enhancing blood-stage malaria subunit vaccine immunogenicity in rhesus macaques by combining adenovirus, poxvirus, and protein-in-adjuvant vaccines. J. Immunol. 185, 7583-7595. doi: 10.4049/jimmunol.1001760

Draper, S. J., Cottingham, M. G., and Gilbert, S. C. (2013). Utilizing poxviral vectored vaccines for antibody induction-progress and prospects. Vaccine 31, 4223-4230. doi: 10.1016/j.vaccine.2013.05.091

Draper, S. J., Moore, A. C., Goodman, A. L., Long, C. A., Holder, A. A., Gilbert, S. C., et al. (2008). Effective induction of high-titer antibodies by viral vector vaccines. Nat. Med. 14, 819-821. doi: 10.1038/nm.1850
Dumais, N., Patrick, A., Moss, R. B., Davis, H. L., and Rosenthal, K. L. (2002). Mucosal immunization with inactivated human immunodeficiency virus plus $\mathrm{CpG}$ oligodeoxynucleotides induces genital immune responses and protection against intravaginal challenge. J. Infect. Dis. 186, 1098-1105. doi: $10.1086 / 344232$

Dunachie, S. J., Walther, M., Epstein, J. E., Keating, S., Berthoud, T., Andrews, L., et al. (2006). A DNA prime-modified vaccinia virus ankara boost vaccine encoding thrombospondin-related adhesion protein but not circumsporozoite protein partially protects healthy malaria-naive adults against Plasmodium falciparum sporozoite challenge. Infect. Immun. 74, 5933-5942. doi: 10.1128/IAI.00590-06

Egan, M. A., Chong, S. Y., Megati, S., Montefiori, D. C., Rose, N. F., Boyer, J. D., et al. (2005). Priming with plasmid DNAs expressing interleukin-12 and simian immunodeficiency virus gag enhances the immunogenicity and efficacy of an experimental AIDS vaccine based on recombinant vesicular stomatitis virus. AIDS Res. Hum. Retroviruses 21, 629-643. doi: 10.1089/aid.2005.21.629

Egan, M. A., Chong, S. Y., Rose, N. F., Megati, S., Lopez, K. J., Schadeck, E. B., et al. (2004). Immunogenicity of attenuated vesicular stomatitis virus vectors expressing HIV type 1 Env and SIV Gag proteins: comparison of intranasal and intramuscular vaccination routes. AIDS Res. Hum. Retroviruses 20, 989-1004. doi: 10.1089/0889222042222746

Emini, E. A., and Koff, W. C. (2004). AIDS/HIV. Developing an AIDS vaccine: need, uncertainty, hope. Science 304, 1913-1914. doi: 10.1126/science.1100368

Ersching, J., Hernandez, M. I., Cezarotto, F. S., Ferreira, J. D., Martins, A. B., Switzer, W. M., et al. (2010). Neutralizing antibodies to human and simian adenoviruses in humans and New-World monkeys. Virology 407, 1-6. doi: 10.1016/j.virol.2010.07.043

Estcourt, M. J., Ramsay, A. J., Brooks, A., Thomson, S. A., Medveckzy, C. J., and Ramshaw, I. A. (2002). Prime-boost immunization generates a high frequency, high-avidity $\mathrm{CD} 8(+)$ cytotoxic $\mathrm{T}$ lymphocyte population. Int. Immunol. 14, 31-37. doi: 10.1093/intimm/14.1.31

Evans, T. G., Keefer, M. C., Weinhold, K. J., Wolff, M., Montefiori, D., Gorse, G. J., et al. (1999). A canarypox vaccine expressing multiple human immunodeficiency virus type 1 genes given alone or with rgp120 elicits broad and durable CD8+ cytotoxic T lymphocyte responses in seronegative volunteers. J. Infect. Dis. 180, 290-298. doi: 10.1086/314895

Excler, J. L., Parks, C. L., Ackland, J., Rees, H., Gust, I. D., and Koff, W. C. (2010). Replicating viral vectors as HIV vaccines: summary report from the IAVIsponsored satellite symposium at the AIDS vaccine 2009 conference. Biologicals 38, 511-521. doi: 10.1016/j.biologicals.2010.03.005

Faul, E. J., Aye, P. P., Papaneri, A. B., Pahar, B., McGettigan, J. P., Schiro, F., et al. (2009). Rabies virus-based vaccines elicit neutralizing antibodies, poly-functional CD8+ $\mathrm{T}$ cell, and protect rhesus macaques from AIDS-like disease after SIV(mac251) challenge. Vaccine 28, 299-308. doi: 10.1016/j.vaccine.2009.10.051

Finn, J. D., Bassett, J., Millar, J. B., Grinshtein, N., Yang, T. C., Parsons, R., et al. (2009). Persistence of transgene expression influences CD8+ T-cell expansion and maintenance following immunization with recombinant adenovirus. J. Virol. 83, 12027-12036. doi: 10.1128/JVI.00593-09

Fitzgerald, J. C., Gao, G. P., Reyes-Sandoval, A., Pavlakis, G. N., Xiang, Z. Q., Wlazlo, A. P., et al. (2003). A simian replication-defective adenoviral recombinant vaccine to HIV-1 gag. J. Immunol. 170, 1416-1422. doi: 10.4049/jimmunol.170.3.1416

Flynn, N. M., Forthal, D. N., Harro, C. D., Judson, F. N., Mayer, K. H., Para, M. F., et al. (2005). Placebo-controlled phase 3 trial of a recombinant glycoprotein 120 vaccine to prevent HIV-1 infection. J. Infect. Dis. 191, 654-665. doi: $10.1086 / 428404$

Frahm, N., DeCamp, A. C., Friedrich, D. P., Carter, D. K., Defawe, O. D., Kublin, J. G., et al. (2012). Human adenovirus-specific T cells modulate HIV-specific T cell responses to an Ad5-vectored HIV-1 vaccine. J. Clin. Invest. 122, 359-367. doi: 10.1172/JCI60202

Fuchs, J., Frank, I., Kochar, N., Elizaga, M., Allen, M., Carter, D., et al. (2012) First-in-human phase I clinical trial of a recombinant vesicular stomatitis virus (rVSV)-based preventive HIV-1 vaccine. Retrovirology 9, P134. doi: 10.1186/1742-4690-9-S2-P134

Fuchs, J., Frank, I., Kochar, N., Elizaga, M., Allen, M., Frahm, N., et al. (2013). A Recombinant Vesicular Stomatitis Virus (rVSV) HIV-1 gag Vaccine is Safe And Immunogenic in Healthy, HIV-1 Uninfected Phase I Trial Participants. Barcelona: AIDS vaccine. 
Gabitzsch, E. S., Xu, Y., Yoshida, L. H., Balint, J., Amalfitano, A., and Jones, F. R. (2009). Novel Adenovirus type 5 vaccine platform induces cellular immunity against HIV-1 Gag, Pol, Nef despite the presence of Ad5 immunity. Vaccine 27, 6394-6398. doi: 10.1016/j.vaccine.2009.06.028

Gaggar, A., Shayakhmetov, D. M., and Lieber, A. (2003). CD46 is a cellular receptor for group B adenoviruses. Nat. Med. 9, 1408-1412. doi: 10.1038/nm952

Garcia, F., Bernaldo de Quiros, J. C., Gomez, C. E., Perdiguero, B., Najera, J. L., Jimenez, V., et al. (2011). Safety and immunogenicity of a modified pox vector-based HIV/AIDS vaccine candidate expressing Env, Gag, Pol and Nef proteins of HIV-1 subtype B (MVA-B) in healthy HIV-1-uninfected volunteers: a phase I clinical trial (RISVAC02). Vaccine 29, 8309-8316. doi: 10.1016/j.vaccine.2011.08.098

Garcia-Arriaza, J., Arnaez, P., Gomez, C. E., Sorzano, C. O., and Esteban, M. (2013). Improving adaptive and memory immune responses of an HIV/AIDS Vaccine Candidate MVA-B by deletion of vaccinia virus genes (C6L and K7R) blocking interferon signaling pathways. PLOS ONE 8:e66894. doi: 10.1371/journal.pone.0066894

Garcia-Hernandez, E., Gonzalez-Sanchez, J. L., Andrade-Manzano, A., Contreras, M. L., Padilla, S., Guzman, C. C., et al. (2006). Regression of papilloma high-grade lesions (CIN 2 and CIN 3 ) is stimulated by therapeutic vaccination with MVA E2 recombinant vaccine. Cancer Gene Ther. 13, 592-597. doi: 10.1038/sj.cgt.7700937

Garcia-Sastre, A., and Palese, P. (1995). Influenza virus vectors. Biologicals 23, 171-178.

Garver, K. A., LaPatra, S. E., and Kurath, G. (2005). Efficacy of an infectious hematopoietic necrosis (IHN) virus DNA vaccine in Chinook Oncorhynchus tshawytscha and sockeye O. nerka salmon. Dis. Aquat. Organ. 64, 13-22. doi: 10.3354/dao064013

Gherardi, M. M., and Esteban, M. (1999). Mucosal and systemic immune responses induced after oral delivery of vaccinia virus recombinants. Vaccine 17, 1074-1083.

Gherardi, M. M., and Esteban, M. (2005). Recombinant poxviruses as mucosal vaccine vectors. J. Gen. Virol.86(Pt 11), 2925-2936. doi: 10.1099/vir.0. 81181-0

Gherardi, M. M., Najera, J. L., Perez-Jimenez, E., Guerra, S., Garcia-Sastre, A., and Esteban, M. (2003). Prime-boost immunization schedules based on influenza virus and vaccinia virus vectors potentiate cellular immune responses against human immunodeficiency virus Env protein systemically and in the genitorectal draining lymph nodes. J. Virol. 77, 7048-7057. doi: 10.1128/JVI.77.12.70487057.2003

Gherardi, M. M., Perez-Jimenez, E., Najera, J. L., and Esteban, M. (2004). Induction of HIV immunity in the genital tract after intranasal delivery of a MVA vector: enhanced immunogenicity after DNA prime-modified vaccinia virus Ankara boost immunization schedule. J. Immunol. 172, 6209-6220. doi: 10.4049/jimmunol.172.10.6209

Gherardi, M. M., Ramirez, J. C., and Esteban, M. (2000). Interleukin-12 (IL-12) enhancement of the cellular immune response against human immunodeficiency virus type 1 env antigen in a DNA prime/vaccinia virus boost vaccine regimen is time and dose dependent: suppressive effects of IL-12 boost are mediated by nitric oxide. J. Virol. 74, 6278-6286. doi: 10.1128/JVI.74.14.62786286.2000

Gherardi, M. M., Ramirez, J. C., Rodriguez, D., Rodriguez, J. R., Sano, G., Zavala, F., et al. (1999). IL-12 delivery from recombinant vaccinia virus attenuates the vector and enhances the cellular immune response against HIV-1 Env in a dosedependent manner. J. Immunol. 162, 6724-6733.

Gilbert, P. B., Peterson, M. L., Follmann, D., Hudgens, M. G., Francis, D. P., Gurwith, M., et al. (2005). Correlation between immunologic responses to a recombinant glycoprotein 120 vaccine and incidence of HIV-1 infection in a phase 3 HIV-1 preventive vaccine trial. J. Infect. Dis. 191, 666-677. doi: $10.1086 / 428405$

Gilbert, S. C., Schneider, J., Hannan, C. M., Hu, J. T., Plebanski, M., Sinden, R., et al. (2002). Enhanced CD8 T cell immunogenicity and protective efficacy in a mouse malaria model using a recombinant adenoviral vaccine in heterologous prime-boost immunisation regimes. Vaccine 20, 1039-1045. doi: 10.1016/S0264-410X(01)00450-9

Gilbert, S. C., Schneider, J., Plebanski, M., Hannan, C. M., Blanchard, T. J., Smith, G. L., et al. (1999). Ty virus-like particles, DNA vaccines and Modified Vaccinia Virus Ankara; comparisons and combinations. Biol. Chem. 380, 299-303. doi: 10.1515/BC.1999.041
Gillmore, J. D., Tennent, G. A., Hutchinson, W. L., Gallimore, J. R., Lachmann, H. J., Goodman, H. J., et al. (2010). Sustained pharmacological depletion of serum amyloid $\mathrm{P}$ component in patients with systemic amyloidosis. Br. J. Haematol. 148, 760-767. doi: 10.1111/j.1365-2141.2009.08036.x

Goepfert, P. A., Elizaga, M. L., Sato, A., Qin, L., Cardinali, M., Hay, C. M., et al. (2011). Phase 1 safety and immunogenicity testing of DNA and recombinant modified vaccinia Ankara vaccines expressing HIV-1 virus-like particles. J. Infect. Dis. 203, 610-619. doi: 10.1093/infdis/jiq105

Gomez, C. E., Najera, J. L., Perdiguero, B., Garcia-Arriaza, J., Sorzano, C. O., Jimenez, V., et al. (2011). The HIV/AIDS vaccine candidate MVA-B administered as a single immunogen in humans triggers robust, polyfunctional, and selective effector memory $\mathrm{T}$ cell responses to HIV-1 antigens. J. Virol. 85, 11468-11478. doi: 10.1128/JVI.05165-11

Gomez, C. E., Perdiguero, B., Najera, J. L., Sorzano, C. O., Jimenez, V., GonzalezSanz, R., et al. (2012). Removal of vaccinia virus genes that block interferon type I and II pathways improves adaptive and memory responses of the HIV/AIDS vaccine candidate NYVAC-C in mice. J. Virol. 86, 5026-5038. doi: 10.1128/JVI.06684-11

Goonetilleke, N., Moore, S., Dally, L., Winstone, N., Cebere, I., Mahmoud, A., et al. (2006). Induction of multifunctional human immunodeficiency virus type 1 (HIV-1)-specific T cells capable of proliferation in healthy subjects by using a prime-boost regimen of DNA- and modified vaccinia virus Ankara-vectored vaccines expressing HIV-1 Gag coupled to CD8+ T-cell epitopes. J. Virol. 80, 4717-4728. doi: 10.1128/JVI.80.10.4717-4728.2006

Graham, B. S., Enama, M. E., Nason, M. C., Gordon, I. J., Peel, S. A., Ledgerwood, J. E., et al. (2013). DNA vaccine delivered by a needle-free injection device improves potency of priming for antibody and CD8+ T-cell responses after rAd5 boost in a randomized clinical trial. PLoS ONE 8:e59340. doi: 10.1371/journal.pone.0059340

Graham, B. S., Koup, R. A., Roederer, M., Bailer, R. T., Enama, M. E., Moodie, Z., et al. (2006). Phase 1 safety and immunogenicity evaluation of a multiclade HIV-1 DNA candidate vaccine. J. Infect. Dis. 194, 1650-1660. doi: $10.1086 / 509259$

Gray, G. E., Allen, M., Moodie, Z., Churchyard, G., Bekker, L. G., Nchabeleng, M., et al. (2011). Safety and efficacy of the HVTN 503/Phambili study of a cladeB-based HIV-1 vaccine in South Africa: a double-blind, randomised, placebocontrolled test-of-concept phase 2b study. Lancet Infect. Dis. 11, 507-515. doi: 10.1016/S1473-3099

Greenough, T. C., Cunningham, C. K., Muresan, P., McManus, M., Persaud, D., Fenton, T., et al. (2008). Safety and immunogenicity of recombinant poxvirus HIV-1 vaccines in young adults on highly active antiretroviral therapy. Vaccine 26, 6883-6893. doi: 10.1016/j.vaccine.2008.09.084

Gudmundsdotter, L., Nilsson, C., Brave, A., Hejdeman, B., Earl, P., Moss, B., et al. (2009). Recombinant Modified Vaccinia Ankara (MVA) effectively boosts DNAprimed HIV-specific immune responses in humans despite pre-existing vaccinia immunity. Vaccine 27, 4468-4474. doi: 10.1016/j.vaccine.2009.05.018

Guimaraes-Walker, A., Mackie, N., McCormack, S., Hanke, T., Schmidt, C. Gilmour, J., et al. (2008). Lessons from IAVI-006, a phase I clinical trial to evaluate the safety and immunogenicity of the pTHr.HIVA DNA and MVA.HIVA vaccines in a prime-boost strategy to induce HIV-1 specific T-cell responses in healthy volunteers. Vaccine 26, 6671-6677. doi: 10.1016/j.vaccine.2008.09.016

Haglund, K., Leiner, I., Kerksiek, K., Buonocore, L., Pamer, E., and Rose, J. K. (2002). Robust recall and long-term memory T-cell responses induced by prime-boost regimens with heterologous live viral vectors expressing human immunodeficiency virus type $1 \mathrm{Gag}$ and Env proteins. J. Virol. 76, 7506-7517. doi: 10.1128/JVI.76.15.7506-7517.2002

Hammer, S. M., Sobieszczyk, M. E., Janes, H., Karuna, S. T., Mulligan, M. J., Grove, D., et al. (2013). Efficacy trial of a DNA/rAd5 HIV-1 preventive vaccine. N. Engl. J. Med. 369, 2083-2092. doi: 10.1056/NEJMoa1310566

Hansen, S. G., Ford, J. C., Lewis, M. S., Ventura, A. B., Hughes, C. M., CoyneJohnson, L., et al. (2011). Profound early control of highly pathogenic SIV by an effector memory T-cell vaccine. Nature 473, 523-527. doi: 10.1038/nature10003

Hansen, S. G., Piatak, M. Jr., Ventura, A. B., Hughes, C. M., Gilbride, R. M., Ford, J. C., et al. (2013). Immune clearance of highly pathogenic SIV infection. Nature 502, 100-104. doi: 10.1038/nature12519

Hansen, S. G., Vieville, C., Whizin, N., Coyne-Johnson, L., Siess, D. C., Drummond, D. D., et al. (2009). Effector memory $\mathrm{T}$ cell responses are associated with protection of rhesus monkeys from mucosal simian immunodeficiency virus challenge. Nat. Med. 15, 293-299. doi: 10.1038/nm.1935 
Harari, A., Bart, P. A., Stohr, W., Tapia, G., Garcia, M., Medjitna-Rais, E., et al. (2008). An HIV-1 clade C DNA prime, NYVAC boost vaccine regimen induces reliable, polyfunctional, and long-lasting T cell responses. J. Exp. Med. 205, 63-77. doi: 10.1084/jem.20071331

Harari, A., Rozot, V., Cavassini, M., Enders, F. B., Vigano, S., Tapia, G., et al. (2012). NYVAC immunization induces polyfunctional HIV-specific T-cell responses in chronically-infected, ART-treated HIV patients. Eur. J. Immunol. 42, 3038-3048. doi: 10.1002/eji.201242696

Harrop, R., Connolly, N., Redchenko, I., Valle, J., Saunders, M., Ryan, M. G., et al. (2006). Vaccination of colorectal cancer patients with modified vaccinia Ankara delivering the tumor antigen 5T4 (TroVax) induces immune responses which correlate with disease control: a phase I/II trial. Clin. Cancer Res. 12(Pt 1), 3416-3424. doi: 10.1158/1078-0432.CCR-05-2732

Haut, L. H., Lin, S. W., Tatsis, N., DiMenna, L. J., Giles-Davis, W., Pinto, A. R., et al. (2010). Robust genital gag-specific CD8+ T-cell responses in mice upon intramuscular immunization with simian adenoviral vectors expressing HIV-1gag. Eur. J. Immunol. 40, 3426-3438. doi: 10.1002/eji.201040440

He, Z., Wlazlo, A. P., Kowalczyk, D. W., Cheng, J., Xiang, Z. Q., Giles-Davis, W. et al. (2000). Viral recombinant vaccines to the E6 and E7 antigens of HPV-16. Virology 270, 146-161. doi: 10.1006/viro.2000.0271

Hel, Z., Tsai, W. P., Thornton, A., Nacsa, J., Giuliani, L., Tryniszewska, E., et al. (2001). Potentiation of simian immunodeficiency virus (SIV)-specific CD4 $(+)$ and CD8(+) T cell responses by a DNA-SIV and NYVAC-SIV prime/boost regimen. J. Immunol. 167, 7180-7191. doi: 10.4049/jimmunol.167.12.7180

Hemelaar, J., Gouws, E., Ghys, P. D., Osmanov, S., and Isolation W-UNfH, Characterisation. (2011). Global trends in molecular epidemiology of HIV-1 during 2000-2007. AIDS 25, 679-689. doi: 10.1097/QAD.0b013e328342ff93

Hensley, S. E., Giles-Davis, W., McCoy, K. C., Weninger, W., and Ertl, H. C. (2005). Dendritic cell maturation, but not CD8+ T cell induction, is dependent on type I IFN signaling during vaccination with adenovirus vectors. J. Immunol. 175, 6032-6041. doi: 10.4049/jimmunol.175.9.6032

Hill, A. V., Reyes-Sandoval, A., O’Hara, G., Ewer, K., Lawrie, A., Goodman, A., et al. (2010). Prime-boost vectored malaria vaccines: progress and prospects. Hum. Vaccin. 6, 78-83. doi: 10.4161/hv.6.1.10116

Hoke, C. H. Jr., and Snyder, C. E. Jr. (2013). History of the restoration of adenovirus type 4 and type 7 vaccine, live oral (Adenovirus Vaccine) in the context of the Department of Defense acquisition system. Vaccine 31, 1623-1632. doi: 10.1016/j.vaccine.2012.12.029

Holmgren, J., and Czerkinsky, C. (2005). Mucosal immunity and vaccines. Nat. Med. 11, S45-53. doi: 10.1038/nm1213

Holmgren, J., Czerkinsky, C., Eriksson, K., and Mharandi, A. (2003). Mucosal immunisation and adjuvants: a brief overview of recent advances and challenges. Vaccine 21(Suppl. 2), S89-S95. doi: 10.1016/S0264-410X(03)00206-8

Holterman, L., Vogels, R., van der Vlugt, R., Sieuwerts, M., Grimbergen, J., Kaspers, J., et al. (2004). Novel replication-incompetent vector derived from adenovirus type 11 (Ad11) for vaccination and gene therapy: low seroprevalence and non-cross-reactivity with Ad5. J. Virol. 78, 13207-13215. doi: 10.1128/JVI.78.23.13207-13215.2004

Hopkins, R., Bridgeman, A., Bourne, C., Mbewe-Mvula, A., Sadoff, J. C., Both, G. W., et al. (2011a). Optimizing HIV-1-specific CD8+ T-cell induction by recombinant BCG in prime-boost regimens with heterologous viral vectors. Eur. J. Immunol. 41, 3542-3552. doi: 10.1002/eji.201141962

Hopkins, R., Bridgeman, A., Joseph, J., Gilbert, S. C., McShane, H., and Hanke, T., (2011b). Dual neonate vaccine platform against HIV-1 and M. tuberculosis. PLoS ONE 6:e20067. doi: 10.1371/journal.pone.0020067

Horner, A. A., Datta, S. K., Takabayashi, K., Belyakov, I. M., Hayashi, T., Cinman, N., et al. (2001). Immunostimulatory DNA-based vaccines elicit multifaceted immune responses against HIV at systemic and mucosal sites. J. Immunol. 167, 1584-1591. doi: 10.4049/jimmunol.167.3.1584

Howles, S., Guimaraes-Walker, A., Yang, H., Hancock, G., di Gleria, K., TarragonaFiol, T., et al. (2010). Vaccination with a modified vaccinia virus Ankara (MVA)vectored HIV-1 immunogen induces modest vector-specific T cell responses in human subjects. Vaccine 28, 7306-7312. doi: 10.1016/j.vaccine.2010.08.077

Hu, K., Luo, S., Tong, L., Huang, X., Jin, W., Huang, W., et al. (2013). CCL19 and CCL28 augment mucosal and systemic immune responses to HIV-1 gp140 by mobilizing responsive immunocytes into secondary lymph nodes and mucosal tissue. J. Immunol. 191, 1935-1947. doi: 10.4049/jimmunol.1300120

Huster, K. M., Koffler, M., Stemberger, C., Schiemann, M., Wagner, H., and Busch, D. H. (2006). Unidirectional development of CD8+ central memory T cells into protective Listeria-specific effector memory T cells. Eur. J. Immunol. 36, 1453-1464. doi: 10.1002/eji.200635874

Hutnick, N. A., Carnathan, D. G., Dubey, S. A., Cox, K. S., Kierstead, L., Makadonas, G., et al. (2010). Vaccination with Ad5 vectors expands Ad5-specific CD8 T cells without altering memory phenotype or functionality. PLoS ONE 5:e14385. doi: 10.1371/journal.pone.0014385

Jalah, R., Kulkarni, V., Patel, V., Rosati, M., Alicea, C., Bear, J., et al. (2014). DNA and protein co-immunization improves the magnitude and longevity of humoral immune responses in macaques. PLoS ONE 9:e91550. doi: 10.1371/journal.pone.0091550

Jiang, J. Q., Patrick, A., Moss, R. B., and Rosenthal, K. L. (2005). CD8+ Tcell-mediated cross-clade protection in the genital tract following intranasal immunization with inactivated human immunodeficiency virus antigen plus CpG oligodeoxynucleotides. J. Virol. 79, 393-400. doi: 10.1128/JVI.79.1.393400.2005

Kalams, S. A., Parker, S., Jin, X., Elizaga, M., Metch, B., Wang, M., et al. (2012) Safety and immunogenicity of an HIV-1 gag DNA vaccine with or without IL12 and/or IL-15 plasmid cytokine adjuvant in healthy, HIV-1 uninfected adults. PLoS ONE 7:e29231. doi: 10.1371/journal.pone.0029231

Kalams, S. A., Parker, S. D., Elizaga, M., Metch, B., Edupuganti, S., Hural, J., et al. (2013). Safety and comparative immunogenicity of an HIV-1 DNA vaccine in combination with plasmid interleukin 12 and impact of intramuscular electroporation for delivery. J. Infect. Dis. 208, 818-829. doi: 10.1093/infdis/ jit236

Kaleebu, P., Njai, H. F., Wang, L., Jones, N., Ssewanyana, I., Richardson, P., et al. (2014). Immunogenicity of ALVAC-HIV vCP1521 in infants of HIV1-infected women in Uganda (HPTN 027): the first pediatric HIV vaccine trial in Africa. J. Acquir. Immune Defic. Syndr. 65, 268-277. doi: 10.1097/01.qai.0000435600.65845.31

Kawada, M., Tsukamoto, T., Yamamoto, H., Takeda, A., Igarashi, H., Watkins, D. I., et al. (2007). Long-term control of simian immunodeficiency virus replication with central memory $\mathrm{CD} 4+\mathrm{T}$-cell preservation after nonsterile protection by a cytotoxic T-lymphocyte-based vaccine. J. Virol. 81, 5202-5211. doi: 10.1128/JVI.02881-06

Keefer, M. C., Frey, S. E., Elizaga, M., Metch, B., De Rosa, S. C., Barroso, P. F., et al. (2011). A phase I trial of preventive HIV vaccination with heterologous poxviral-vectors containing matching HIV-1 inserts in healthy HIV-uninfected subjects. Vaccine 29, 1948-1958. doi: 10.1016/j.vaccine.2010.12.104

Keefer, M. C., Gilmour, J., Hayes, P., Gill, D., Kopycinski, J., Cheeseman, H., et al. (2012). A phase I double blind, placebo-controlled, randomized study of a multigenic HIV-1 adenovirus subtype 35 vector vaccine in healthy uninfected adults. PLoS ONE 7:e41936. doi: 10.1371/journal.pone.0041936

Kennedy, J. S., Co, M., Green, S., Longtine, K., Longtine, J., O’Neill, M. A., et al. (2008). The safety and tolerability of an HIV-1 DNA prime-protein boost vaccine (DP6-001) in healthy adult volunteers. Vaccine 26, 4420-4424. doi: 10.1016/j.vaccine.2008.05.090

Kent, S. J., Zhao, A., Best, S. J., Chandler, J. D., Boyle, D. B., and Ramshaw, I. A. (1998). Enhanced T-cell immunogenicity and protective efficacy of a human immunodeficiency virus type 1 vaccine regimen consisting of consecutive priming with DNA and boosting with recombinant fowlpox virus. J. Virol. 72, 10180-10188.

Kibler, K. V., Gomez, C. E., Perdiguero, B., Wong, S., Huynh, T., Holechek, S., et al. (2011). Improved NYVAC-based vaccine vectors. PLoS ONE 6:e25674. doi: 10.1371/journal.pone.0025674

Kim, T. S., Hufford, M. M., Sun, J., Fu, Y. X., and Braciale, T. J. (2010). Antigen persistence and the control of local $\mathrm{T}$ cell memory by migrant respiratory dendritic cells after acute virus infection. J. Exp. Med. 207, 1161-1172. doi: 10.1084/jem.20092017

Kintu, K., Andrew, P., Musoke, P., Richardson, P., Asiimwe-Kateera, B., Nakyanzi, T., et al. (2013). Feasibility and safety of ALVAC-HIV vCP1521 vaccine in HIV-exposed infants in Uganda: results from the first HIV vaccine trial in infants in Africa. J. Acquir. Immune Defic. Syndr. 63, 1-8. doi: 10.1097/QAI.0b013e31827f1c2d

Kiyono, H., and Fukuyama, S. (2004). NALT- versus Peyer's-patch-mediated mucosal immunity. Nat. Rev. Immunol. 4, 699-710. doi: 10.1038/nri1439

Kong, W. P., Wu, L., Wallstrom, T. C., Fischer, W., Yang, Z. Y., Ko, S. Y., et al. (2009). Expanded breadth of the T-cell response to mosaic human immunodeficiency virus type 1 envelope DNA vaccination. J. Virol. 83, 2201-2215. doi: 10.1128/JVI.02256-08 
Kopycinski, J., Cheeseman, H., Ashraf, A., Gill, D., Hayes, P., Hannaman, D., et al. (2012). A DNA-based candidate HIV vaccine delivered via in vivo electroporation induces CD4 responses toward the alpha4beta7-binding V2 loop of HIV gp120 in healthy volunteers. Clin. Vaccine Immunol. 19, 1557-1559. doi: 10.1128/CVI.00327-12

Korber, B. T., Letvin, N. L., and Haynes, B. F. (2009). T-cell vaccine strategies for human immunodeficiency virus, the virus with a thousand faces. J. Virol. 83, 8300-8314. doi: 10.1128/JVI.00114-09

Kurath, G., Garver, K. A., Corbeil, S., Elliott, D. G., Anderson, E. D., and LaPatra, S. E. (2006). Protective immunity and lack of histopathological damage two years after DNA vaccination against infectious hematopoietic necrosis virus in trout. Vaccine 24, 345-354. doi: 10.1016/j.vaccine.2005.07.068

Lai, L., Kwa, S., Kozlowski, P. A., Montefiori, D. C., Ferrari, G., Johnson, W. E., et al. (2011). Prevention of infection by a granulocyte-macrophage colony-stimulating factor co-expressing DNA/modified vaccinia Ankara simian immunodeficiency virus vaccine. J. Infect. Dis. 204, 164-173. doi: 10.1093/infdis/jir199

Lasaro, M. O., and Ertl, H. C. (2009). New insights on adenovirus as vaccine vectors. Mol. Ther. 17, 1333-1339. doi: 10.1038/mt.2009.130

Leroux-Roels, G., Maes, C., Clement, F., van Engelenburg, F., van den Dobbelsteen, M., Adler, M., et al. (2013). Randomized phase I: safety, immunogenicity and mucosal antiviral activity in young healthy women vaccinated with HIV-1 Gp41 P1 peptide on virosomes. PLoS ONE 8:e55438. doi: 10.1371/journal.pone. 0055438

Letourneau, S., Im, E. J., Mashishi, T., Brereton, C., Bridgeman, A., Yang, H., et al. (2007). Design and pre-clinical evaluation of a universal HIV-1 vaccine. PLoS ONE 2:e984. doi: 10.1371/journal.pone.0000984

Li, J., Arevalo, M. T., and Zeng, M. (2013). Engineering influenza viral vectors. Bioengineered 4, 9-14. doi: 10.4161/bioe.21950

Li, S., Polonis, V., Isobe, H., Zaghouani, H., Guinea, R., Moran, T., et al. (1993a). Chimeric influenza virus induces neutralizing antibodies and cytotoxic $\mathrm{T}$ cells against human immunodeficiency virus type 1. J. Virol. 67, 6659-6666.

Li, S., Rodrigues, M., Rodriguez, D., Rodriguez, J. R., Esteban, M., Palese, P., et al. (1993b). Priming with recombinant influenza virus followed by administration of recombinant vaccinia virus induces $\mathrm{CD} 8+\mathrm{T}$-cell-mediated protective immunity against malaria. Proc. Natl. Acad. Sci. U.S.A. 90, 5214-5218.

Lietz, R., Bayer, W., Ontikatze, T., Johrden, L., Tenbusch, M., Storcksdieck Genannt Bonsmann, M., et al. (2012). Codelivery of the chemokine CCL3 by an adenovirus-based vaccine improves protection from retrovirus infection. J. Virol. 86, 1706-1716. doi: 10.1128/JVI.06244-11

Lillie, P. J., Berthoud, T. K., Powell, T. J., Lambe, T., Mullarkey, C., Spencer, A. J., et al. (2012). Preliminary assessment of the efficacy of a T-cell-based influenza vaccine, MVA-NP+M1, in humans. Clin. Infect. Dis. 55, 19-25. doi $10.1093 / \mathrm{cid} / \mathrm{cis} 327$

Liu, C., Du, S., Li, C., Wang, Y., Wang, M., Li, Y., et al. (2013). Immunogenicity analysis following human immunodeficiency virus recombinant DNA and recombinant vaccinia virus Tian Tan prime-boost immunization. Sci. China Life Sci. 56, 531-540. doi: 10.1007/s11427-013-4484-2

Liu, J., O’Brien, K. L., Lynch, D. M., Simmons, N. L., La Porte, A., Riggs, A. M., et al. (2009). Immune control of an SIV challenge by a T-cell-based vaccine in rhesus monkeys. Nature 457, 87-91. doi: 10.1038/nature07469

Lopez-Gordo, E., Podgorski, I. I., Downes, N., and Alemany, R. (2014). Circumventing antivector immunity: potential use of nonhuman adenoviral vectors. Hum. Gene Ther. 25, 285-300. doi: 10.1089/hum.2013.228

Luo, X. M., Maarschalk, E., O'Connell, R. M., Wang, P., Yang, L., and Baltimore, D. (2009). Engineering human hematopoietic stem/progenitor cells to produce a broadly neutralizing anti-HIV antibody after in vitro maturation to human $\mathrm{B}$ lymphocytes. Blood 113, 1422-1431. doi: 10.1182/blood-2008-09-177139

Mahnel, H., and Mayr, A. (1994). [Experiences with immunization against orthopox viruses of humans and animals using vaccine strain MVA]. Berl. Munch. Tierarztl. Wochenschr. 107, 253-256.

Makitalo, B., Lundholm, P., Hinkula, J., Nilsson, C., Karlen, K., Morner, A., et al. (2004). Enhanced cellular immunity and systemic control of SHIV infection by combined parenteral and mucosal administration of a DNA prime MVA boost vaccine regimen. J. Gen. Virol. 85(Pt 8), 2407-2419. doi: 10.1099/vir.0.79869-0

Mann, J. F., McKay, P. F., Fiserova, A., Klein, K., Cope, A., Rogers, P., et al. (2014). Enhanced immunogenicity of an HIV-1 DNA vaccine delivered with electroporation via combined intramuscular and intradermal routes. J. Virol. 88, 6959-6969. doi: 10.1128/JVI.00183-14
Masopust, D., Ha, S. J., Vezys, V., and Ahmed, R. (2006). Stimulation history dictates memory $\mathrm{CD} 8 \mathrm{~T}$ cell phenotype: implications for prime-boost vaccination. J. Immunol. 177, 831-839. doi: 10.4049/jimmunol.177.2.831

Masopust, D., Vezys, V., Marzo, A. L., and Lefrancois, L. (2001). Preferential localization of effector memory cells in nonlymphoid tissue. Science 291, 2413-2417. doi: $10.1126 /$ science. 1058867

Mast, T. C., Kierstead, L., Gupta, S. B., Nikas, A. A., Kallas, E. G., Novitsky, V., et al. (2010). International epidemiology of human pre-existing adenovirus (Ad) type-5, type-6, type-26 and type-36 neutralizing antibodies: correlates of high Ad5 titers and implications for potential HIV vaccine trials. Vaccine 28, 950-957. doi: 10.1016/j.vaccine.2009.10.145

Matano, T., Kano, M., Nakamura, H., Takeda, A., and Nagai, Y. (2001). Rapid appearance of secondary immune responses and protection from acute CD4 depletion after a highly pathogenic immunodeficiency virus challenge in macaques vaccinated with a DNA prime/Sendai virus vector boost regimen. J. Virol. 75, 11891-11896. doi: 10.1128/JVI.75.23.11891-118 196.2001

Mazumder, S., Maji, M., Das, A., and Ali, N. (2011). Potency, efficacy and durability of DNA/DNA, DNA/protein and protein/protein based vaccination using gp63 against Leishmania donovani in BALB/c mice. PLoS ONE 6:e14644. doi: 10.1371/journal.pone.0014644

McConkey, S. J., Reece, W. H., Moorthy, V. S., Webster, D., Dunachie, S., Butcher, G., et al. (2003). Enhanced T-cell immunogenicity of plasmid DNA vaccines boosted by recombinant modified vaccinia virus Ankara in humans. Nat. Med. 9, 729-735. doi: 10.1038/nm881

McCormack, S., Stohr, W., Barber, T., Bart, P. A., Harari, A., Moog, C., et al. (2008). EV02: a Phase I trial to compare the safety and immunogenicity of HIV DNA-C prime-NYVAC-C boost to NYVAC-C alone. Vaccine 26, 3162-3174. doi: 10.1016/j.vaccine.2008.02.072

McCoy, K., Tatsis, N., Korioth-Schmitz, B., Lasaro, M. O., Hensley, S. E., Lin, S. W., et al. (2007). Effect of preexisting immunity to adenovirus human serotype 5 antigens on the immune responses of nonhuman primates to vaccine regimens based on human- or chimpanzee-derived adenovirus vectors. J. Virol. 81, 6594-6604. doi: 10.1128/JVI.02497-06

McElrath, M. J., De Rosa, S. C., Moodie, Z., Dubey, S., Kierstead, L., Janes, H., et al. (2008). HIV-1 vaccine-induced immunity in the test-of-concept Step Study: a case-cohort analysis. Lancet 372, 1894-1905. doi: 10.1016/S01406736(08)61592-5

McKay, P. F., Cope, A. V., Mann, J. F., Joseph, S., Esteban, M., Tatoud, R., et al. (2014). Glucopyranosyl lipid A adjuvant significantly enhances HIV specific T and B cell responses elicited by a DNA-MVA-protein vaccine regimen. PLoS ONE 9:e84707. doi: 10.1371/journal.pone.0084707

McMichael, A. J. (2006). HIV vaccines. Annu. Rev. Immunol. 24, 227-255. doi: 10.1146/annurev.immunol.24.021605.090605

McShane, H. (2002). Prime-boost immunization strategies for infectious diseases. Curr. Opin. Mol. Ther. 4, 23-27.

Mehandru, S., Poles, M. A., Tenner-Racz, K., Horowitz, A., Hurley, A., Hogan, C., et al. (2004). Primary HIV-1 infection is associated with preferential depletion of CD4+ T lymphocytes from effector sites in the gastrointestinal tract. J. Exp. Med. 200, 761-770. doi: 10.1084/jem.20041196

Meyer, H., Sutter, G., and Mayr, A. (1991). Mapping of deletions in the genome of the highly attenuated vaccinia virus MVA and their influence on virulence. J. Gen. Virol. 72(Pt 5), 1031-1038.

Mooij, P., Balla-Jhagihoorsingh, S. S., Koopman, G., Beenhakker, N., van Haaften, P., Baak, I., et al. (2008). Differential CD4+ versus CD8+ T-cell responses elicited by different poxvirus-based human immunodeficiency virus type 1 vaccine candidates provide comparable efficacies in primates. J. Virol. 82, 2975-2988. doi: 10.1128/JVI.02216-07

Moser, C., Amacker, M., Kammer, A. R., Rasi, S., Westerfeld, N., and Zurbriggen, R. (2007). Influenza virosomes as a combined vaccine carrier and adjuvant system for prophylactic and therapeutic immunizations. Expert Rev. Vaccines 6, 711-721. doi: 10.1586/14760584.6.5.711

Muruve, D. A., Petrilli, V., Zaiss, A. K., White, L. R., Clark, S. A., Ross, P. J., et al. (2008). The inflammasome recognizes cytosolic microbial and host DNA and triggers an innate immune response. Nature 452, 103-107. doi: 10.1038/nature06664

Muster, T., Ferko, B., Klima, A., Purtscher, M., Trkola, A., Schulz, P., et al. (1995). Mucosal model of immunization against human immunodeficiency virus type 1 with a chimeric influenza virus. J. Virol. 69, 6678-6686. 
Muster, T., Guinea, R., Trkola, A., Purtscher, M., Klima, A., Steindl, F., et al. (1994). Cross-neutralizing activity against divergent human immunodeficiency virus type 1 isolates induced by the gp41 sequence ELDKWAS. J. Virol. 68, 4031-4034.

Muster, T., Steindl, F., Purtscher, M., Trkola, A., Klima, A., Himmler, G., et al. (1993). A conserved neutralizing epitope on gp41 of human immunodeficiency virus type 1. J. Virol. 67, 6642-6647.

Mwau, M., Cebere, I., Sutton, J., Chikoti, P., Winstone, N., Wee, E. G., et al. (2004). A human immunodeficiency virus 1 (HIV-1) clade A vaccine in clinical trials: stimulation of HIV-specific T-cell responses by DNA and recombinant modified vaccinia virus Ankara (MVA) vaccines in humans. J. Gen. Virol. 85, 911-919. doi: 10.1099/vir.0.19701-0

Nazir, S. A., and Metcalf, J. P. (2005). Innate immune response to adenovirus. J. Investig. Med. 53, 292-304. doi: 10.2310/6650.2005.53605

Newman, M. J. (2002). Heterologous prime-boost vaccination strategies for HIV-1: augmenting cellular immune responses. Curr. Opin. Investig. Drugs 3, 374-378.

Nolz, J. C., and Harty, J. T. (2011). Strategies and implications for prime-boost vaccination to generate memory CD8 T cells. Adv. Exp. Med. Biol. 780:69-83. doi: 10.1007/978-1-4419-5632-3_7

O’Hara, G. A., Duncan, C. J., Ewer, K. J., Collins, K. A., Elias, S. C., Halstead, F. D., et al. (2012). Clinical assessment of a recombinant simian adenovirus ChAd63: a potent new vaccine vector. J. Infect. Dis. 205, 772-781. doi: 10.1093/infdis/jir850

Ohs, I., Windmann, S., Wildner, O., Dittmer, U., and Bayer, W. (2013). Interleukinencoding adenoviral vectors as genetic adjuvant for vaccination against retroviral infection. PLoS ONE 8:e82528. doi: 10.1371/journal.pone.0082528

Olive, M., Eisenlohr, L., Flomenberg, N., Hsu, S., and Flomenberg, P. (2002). The adenovirus capsid protein hexon contains a highly conserved human CD4+ T-cell epitope. Hum. Gene Ther. 13, 1167-1178. doi: 10.1089/104303402320138952

Ondondo, B. O., Yang, H., Dong, T., di Gleria, K., Suttill, A., Conlon, C., et al. (2006). Immunisation with recombinant modified vaccinia virus Ankara expressing HIV-1 gag in HIV-1-infected subjects stimulates broad functional CD4+ T cell responses. Eur. J. Immunol. 36, 2585-2594. doi: 10.1002/eji.200636508

Palese, P., Zavala, F., Muster, T., Nussenzweig, R. S., and Garcia-Sastre, A. (1997). Development of novel influenza virus vaccines and vectors. J. Infect. Dis. 176(Suppl. 1), S45-S49.

Patel, V., Jalah, R., Kulkarni, V., Valentin, A., Rosati, M., Alicea, C., et al. (2013). DNA and virus particle vaccination protects against acquisition and confers control of viremia upon heterologous simian immunodeficiency virus challenge. Proc. Natl. Acad. Sci. U.S.A. 110, 2975-2980. doi: $10.1073 /$ pnas. 1215393110

Patel, V., Valentin, A., Kulkarni, V., Rosati, M., Bergamaschi, C., Jalah, R., et al. (2010). Long-lasting humoral and cellular immune responses and mucosal dissemination after intramuscular DNA immunization. Vaccine 28, 4827-4836. doi: 10.1016/j.vaccine.2010.04.064

Patterson, L. J., and Robert-Guroff, M. (2008). Replicating adenovirus vector prime/protein boost strategies for HIV vaccine development. Expert Opin. Biol. Ther. 8, 1347-1363. doi: 10.1517/14712598.8.9.1347

Perreau, M., Pantaleo, G., and Kremer, E. J. (2008). Activation of a dendritic cell-T cell axis by Ad5 immune complexes creates an improved environment for replication of HIV in T cells. J. Exp. Med. 205, 2717-2725. doi 10.1084/jem.20081786

Pichla-Gollon, S. L., Lin, S. W., Hensley, S. E., Lasaro, M. O., Herkenhoff-Haut, L., Drinker, M., et al. (2009). Effect of preexisting immunity on an adenovirus vaccine vector: in vitro neutralization assays fail to predict inhibition by antiviral antibody in vivo. J. Virol. 83, 5567-5573. doi: 10.1128/JVI.00405-09

Pitisuttithum, P., Gilbert, P., Gurwith, M., Heyward, W., Martin, M., van Griensven, F., et al. (2006). Randomized, double-blind, placebo-controlled efficacy trial of a bivalent recombinant glycoprotein $120 \mathrm{HIV}-1$ vaccine among injection drug users in Bangkok, Thailand. J. Infect. Dis. 194, 1661-1671. doi: 10.1086/508748

Price, P. J., Torres-Dominguez, L. E., Brandmuller, C., Sutter, G., and Lehmann, M. H. (2013). Modified Vaccinia virus Ankara: innate immune activation and induction of cellular signalling. Vaccine 31, 4231-4234. doi: 10.1016/j.vaccine.2013.03.017

Prodger, J. L., Gray, R., Kigozi, G., Nalugoda, F., Galiwango, R., Hirbod, T., et al. (2012). Foreskin T-cell subsets differ substantially from blood with respect to HIV co-receptor expression, inflammatory profile, and memory status. Mucosal Immunol. 5, 121-128. doi: 10.1038/mi.2011.56
Qureshi, H., Ma, Z. M., Huang, Y., Hodge, G., Thomas, M. A., DiPasquale, J., et al. (2012). Low-dose penile SIVmac251 exposure of rhesus macaques infected with adenovirus type 5 (Ad5) and then immunized with a replication-defective Ad5based SIV gag/pol/nef vaccine recapitulates the results of the phase IIb step trial of a similar HIV-1 vaccine. J. Virol. 86, 2239-2250. doi: 10.1128/JVI.06175-11

Ramshaw, I. A., and Ramsay, A. J. (2000). The prime-boost strategy: exciting prospects for improved vaccination. Immunol. Today 21, 163-165. doi: 10.1016/S0167-5699(00)01612-1

Ranasinghe, C., Turner, S. J., McArthur, C., Sutherland, D. B., Kim, J. H., Doherty, P. C., et al. (2007). Mucosal HIV-1 pox virus prime-boost immunization induces high-avidity CD8 $+\mathrm{T}$ cells with regime-dependent cytokine/granzyme B profiles. J. Immunol. 178, 2370-2379. doi: 10.4049/jimmunol.178.4.2370

Ratto-Kim, S., Currier, J. R., Cox, J. H., Excler, J. L., Valencia-Micolta, A., Thelian, D., et al. (2012). Heterologous prime-boost regimens using rAd35 and rMVA vectors elicit stronger cellular immune responses to HIV proteins than homologous regimens. PLoS ONE 7:e45840. doi: 10.1371/journal.pone.0045840

Rerks-Ngarm, S., Paris, R. M., Chunsutthiwat, S., Premsri, N., Namwat, C., Bowonwatanuwong, C., et al. (2013). Extended evaluation of the virologic, immunologic, and clinical course of volunteers who acquired HIV-1 infection in a phase III vaccine trial of ALVAC-HIV and AIDSVAX B/E. J. Infect. Dis. 207, 1195-1205. doi: 10.1093/infdis/jis478

Rerks-Ngarm, S., Pitisuttithum, P., Nitayaphan, S., Kaewkungwal, J., Chiu, J., Paris, R., et al. (2009). Vaccination with ALVAC and AIDSVAX to prevent HIV-1 infection in Thailand. N. Engl. J. Med. 361, 2209-2220. doi: 10.1056/NEJMoa0908492

Reyes-Sandoval, A., Berthoud, T., Alder, N., Siani, L., Gilbert, S. C., Nicosia, A., et al. (2010). Prime-boost immunization with adenoviral and modified vaccinia virus Ankara vectors enhances the durability and polyfunctionality of protective malaria CD8+ T-cell responses. Infect. Immun. 78, 145-153. doi: 10.1128/IAI.00740-09

Reyes-Sandoval, A., Fitzgerald, J. C., Grant, R., Roy, S., Xiang, Z. Q., Li, Y., et al. (2004). Human immunodeficiency virus type 1-specific immune responses in primates upon sequential immunization with adenoviral vaccine carriers of human and simian serotypes. J. Virol. 78, 7392-7399. doi: 10.1128/JVI.78.14.7392-7399.2004

Reyes-Sandoval, A., Sridhar, S., Berthoud, T., Moore, A. C., Harty, J. T., Gilbert, S. C., et al. (2008). Single-dose immunogenicity and protective efficacy of simian adenoviral vectors against Plasmodium berghei. Eur. J. Immunol. 38, 732-741. doi: 10.1002/eji.200737672

Reynolds, M. R., Weiler, A. M., Piaskowski, S. M., Kolar, H. L., Hessell, A. J., Weiker, M., et al. (2010). Macaques vaccinated with simian immunodeficiency virus SIVmac239Delta nef delay acquisition and control replication after repeated low-dose heterologous SIV challenge. J. Virol. 84, 9190-9199. doi: 10.1128/JVI.00041-10

Reynolds, M. R., Weiler, A. M., Weisgrau, K. L., Piaskowski, S. M., Furlott, J. R., Weinfurter, J. T., et al. (2008). Macaques vaccinated with live-attenuated SIV control replication of heterologous virus. J. Exp. Med. 205, 2537-2550. doi: 10.1084/jem.20081524

Roberts, D. M., Nanda, A., Havenga, M. J., Abbink, P., Lynch, D. M., Ewald, B. A., et al. (2006). Hexon-chimaeric adenovirus serotype 5 vectors circumvent preexisting anti-vector immunity. Nature 441, 239-243. doi: 10.1038/nature04721

Robinson, H. L., and Amara, R. R. (2005). T cell vaccines for microbial infections. Nat. Med. 11, S25-S32. doi: 10.1038/nm1212

Rodriguez, D., Rodriguez, J. R., Llorente, M., Vazquez, I., Lucas, P., Esteban, M., et al. (1999). A human immunodeficiency virus type 1 Env-granulocytemacrophage colony-stimulating factor fusion protein enhances the cellular immune response to Env in a vaccinia virus-based vaccine. J. Gen. Virol. 80 (Pt 1), 217-223.

Roederer, M., Keele, B. F., Schmidt, S. D., Mason, R. D., Welles, H. C., Fischer, W., et al. (2014). Immunological and virological mechanisms of vaccine-mediated protection against SIV and HIV. Nature 505, 502-508. doi: 10.1038/nature12893

Rosati, M., Bergamaschi, C., Valentin, A., Kulkarni, V., Jalah, R., Alicea, C., et al. (2009). DNA vaccination in rhesus macaques induces potent immune responses and decreases acute and chronic viremia after SIVmac251 challenge. Proc. Natl. Acad. Sci. U.S.A. 106, 15831-15836. doi: 10.1073/pnas.0902628106

Rosati, M., von Gegerfelt, A., Roth, P., Alicea, C., Valentin, A., Robert-Guroff, M., et al. (2005). DNA vaccines expressing different forms of simian immunodeficiency virus antigens decrease viremia upon SIVmac251 challenge. J. Virol. 79, 8480-8492. doi: 10.1128/JVI.79.13.8480-8492.2005 
Rose, N. F., Marx, P. A., Luckay, A., Nixon, D. F., Moretto, W. J., Donahoe, S. M., et al. (2001). An effective AIDS vaccine based on live attenuated vesicular stomatitis virus recombinants. Cell 106, 539-549. doi: 10.1016/S00928674(01)00482-2

Roshorm, Y., Cottingham, M. G., Potash, M. J., Volsky, D. J., and Hanke, T. (2012). $\mathrm{T}$ cells induced by recombinant chimpanzee adenovirus alone and in primeboost regimens decrease chimeric EcoHIV/NDK challenge virus load. Eur. J. Immunol. 42, 3243-3255. doi: 10.1002/eji.201242624

Sallusto, F., Geginat, J., and Lanzavecchia, A. (2004). Central memory and effector memory T cell subsets: function, generation, and maintenance. Annu. Rev. Immunol. 22, 745-763. doi: 10.1146/annurev.immunol.22.012703.104702

Sandstrom, E., Nilsson, C., Hejdeman, B., Brave, A., Bratt, G., Robb, M., et al. (2008). Broad immunogenicity of a multigene, multiclade HIV-1 DNA vaccine boosted with heterologous HIV-1 recombinant modified vaccinia virus Ankara. J. Infect. Dis. 198, 1482-1490. doi: 10.1086/592507

Santra, S., Liao, H. X., Zhang, R., Muldoon, M., Watson, S., Fischer, W., et al. (2010). Mosaic vaccines elicit CD8 $+\mathrm{T}$ lymphocyte responses that confer enhanced immune coverage of diverse HIV strains in monkeys. Nat. Med. 16, 324-328. doi: 10.1038/nm.2108

Santra, S., Muldoon, M., Watson, S., Buzby, A., Balachandran, H., Carlson, K. R., et al. (2012). Breadth of cellular and humoral immune responses elicited in rhesus monkeys by multi-valent mosaic and consensus immunogens. Virology 428 , 121-127. doi: 10.1016/j.virol.2012.03.012

Saubi, N., Im, E. J., Fernandez-Lloris, R., Gil, O., Cardona, P. J., Gatell, J. M., et al. (2011). Newborn mice vaccination with BCG.HIVA(2)(2)(2) + MVA.HIVA enhances HIV-1-specific immune responses: influence of age and immunization routes. Clin. Dev. Immunol. 2011:516219. doi: 10.1155/2011/516219

Saubi, N., Mbewe-Mvula, A., Gea-Mallorqui, E., Rosario, M., Gatell, J. M., Hanke, T., et al. (2012). Pre-clinical development of BCG.HIVA(CAT), an antibioticfree selection strain, for HIV-TB pediatric vaccine vectored by lysine auxotroph of BCG. PLoS ONE 7:e42559. doi: 10.1371/journal.pone.0042559

Schell, J., Rose, N. F., Fazo, N., Marx, P. A., Hunter, M., Ramsburg, E., et al. (2009). Long-term vaccine protection from AIDS and clearance of viral DNA following SHIV89.6P challenge. Vaccine 27, 979-986. doi: 10.1016/j.vaccine.2008. 12.017

Schell, J. B., Rose, N. F., Bahl, K., Diller, K., Buonocore, L., Hunter, M., et al. (2011). Significant protection against high-dose simian immunodeficiency virus challenge conferred by a new prime-boost vaccine regimen. J. Virol. 85, 5764-5772. doi: 10.1128/JVI.00342-11

Schneider, J., Gilbert, S. C., Blanchard, T. J., Hanke, T., Robson, K. J., Hannan, C. M., et al. (1998). Enhanced immunogenicity for CD8+ T cell induction and complete protective efficacy of malaria DNA vaccination by boosting with modified vaccinia virus Ankara. Nat. Med. 4, 397-402.

Schneider, J., Gilbert, S. C., Hannan, C. M., Degano, P., Prieur, E., Sheu, E. G., et al. (1999). Induction of CD8 + T cells using heterologous prime-boost immunisation strategies. Immunol. Rev. 170, 29-38.

Scriba, T. J., Tameris, M., Smit, E., van der Merwe, L., Hughes, E. J., Kadira, B., et al. (2012). A phase IIa trial of the new tuberculosis vaccine, MVA85A, in HIV- and/or Mycobacterium tuberculosis-infected adults. Am. J. Respir. Crit. Care Med. 185, 769-778. doi: 10.1164/rccm.201108-1548OC

Sedegah, M., Tamminga, C., McGrath, S., House, B., Ganeshan, H., Lejano, J., et al. (2011). Adenovirus 5-vectored P. falciparum vaccine expressing CSP and AMA1. Part A: safety and immunogenicity in seronegative adults. PLoS ONE 6:e24586. doi: 10.1371/journal.pone.0024586

Sekaly, R. P. (2008). The failed HIV Merck vaccine study: a step back or a launching point for future vaccine development? J. Exp. Med. 205, 7-12. doi: 10.1084/jem.20072681

Selby, M., Goldbeck, C., Pertile, T., Walsh, R., and Ulmer, J. (2000). Enhancement of DNA vaccine potency by electroporation in vivo. J. Biotechnol. 83, 147-152. doi: 10.1016/S0168-1656(00)00308-4

Sexton, A., De Rose, R., Reece, J. C., Alcantara, S., Loh, L., Moffat, J. M., et al. (2009). Evaluation of recombinant influenza virus-simian immunodeficiency virus vaccines in macaques. J. Virol. 83, 7619-7628. doi: 10.1128/JVI.00470-09

Sharpe, S., Fooks, A., Lee, J., Hayes, K., Clegg, C., and Cranage, M. (2002). Single oral immunization with replication deficient recombinant adenovirus elicits long-lived transgene-specific cellular and humoral immune responses. Virology 293, 210-216. doi: 10.1006/viro.2001.1281

Sheehy, S. H., Duncan, C. J., Elias, S. C., Biswas, S., Collins, K. A., O’Hara, G. A., et al. (2012). Phase Ia clinical evaluation of the safety and immunogenicity of the Plasmodium falciparum blood-stage antigen AMA1 in ChAd63 and MVA vaccine vectors. PLoS ONE 7:e31208. doi: 10.1371/journal.pone.0031208

Sheehy, S. H., Duncan, C. J., Elias, S. C., Collins, K. A., Ewer, K. J., Spencer, A. J., et al. (2011). Phase Ia clinical evaluation of the Plasmodium falciparum blood-stage antigen MSP1 in ChAd63 and MVA vaccine vectors. Mol. Ther. 19, 2269-2276. doi: 10.1038/mt.2011.176

Shin, H., and Iwasaki, A. (2012). A vaccine strategy that protects against genital herpes by establishing local memory T cells. Nature 491, 463-467. doi: 10.1038/nature11522

Shiver, J. W., Fu, T. M., Chen, L., Casimiro, D. R., Davies, M. E., Evans, R. K., et al. (2002). Replication-incompetent adenoviral vaccine vector elicits effective antiimmunodeficiency-virus immunity. Nature 415, 331-335. doi: 10.1038/415331a

Smaill, F., Jeyanathan, M., Smieja, M., Medina, M. F., Thanthrige-Don, N., Zganiacz, A., et al. (2013). A human type 5 adenovirus-based tuberculosis vaccine induces robust $\mathrm{T}$ cell responses in humans despite preexisting anti-adenovirus immunity. Sci. Transl. Med. 5, 205ra134. doi: 10.1126/scitranslmed.3006843

Smith, G. L., and Moss, B. (1983). Infectious poxvirus vectors have capacity for at least 25000 base pairs of foreign DNA. Gene 25, 21-28.

Spearman, P., Lally, M. A., Elizaga, M., Montefiori, D., Tomaras, G. D., McElrath, M. J., et al. (2011). A trimeric, V2-deleted HIV-1 envelope glycoprotein vaccine elicits potent neutralizing antibodies but limited breadth of neutralization in human volunteers. J. Infect. Dis. 203, 1165-1173. doi: 10.1093/infdis/jiq175

Stevceva, L., Alvarez, X., Lackner, A. A., Tryniszewska, E., Kelsall, B., Nacsa, J., et al. (2002). Both mucosal and systemic routes of immunization with the live, attenuated NYVAC/simian immunodeficiency virus SIV(gpe) recombinant vaccine result in gag-specific CD8(+) T-cell responses in mucosal tissues of macaques. J. Virol. 76, 11659-11676. doi: 10.1128/JVI.76.22.11659-11676.2002

Suleman, M., Galea, S., Gavard, F., Merillon, N., Klonjkowski, B., Tartour E., et al. (2011). Antigen encoded by vaccine vectors derived from human adenovirus serotype 5 is preferentially presented to CD8+ T lymphocytes by the CD8alpha+ dendritic cell subset. Vaccine 29, 5892-5903. doi: 10.1016/j.vaccine.2011.06.071

Takeda, A., Igarashi, H., Nakamura, H., Kano, M., Iida, A., Hirata, T., et al. (2003) Protective efficacy of an AIDS vaccine, a single DNA priming followed by a single booster with a recombinant replication-defective Sendai virus vector, in a macaque AIDS model. J. Virol. 77, 9710-9715. doi: 10.1128/JVI.77.17.97109715.2003

Tameris, M., Geldenhuys, H., Luabeya, A. K., Smit, E., Hughes, J. E., Vermaak, S., et al. (2014). The candidate TB vaccine, MVA85A, induces highly durable Th1 responses. PLoS ONE 9:e87340. doi: 10.1371/journal.pone.0087340

Tameris, M. D., Hatherill, M., Landry, B. S., Scriba, T. J., Snowden, M. A., Lockhart, S., et al. (2013). Safety and efficacy of MVA85A, a new tuberculosis vaccine, in infants previously vaccinated with BCG: a randomised, placebo-controlled phase 2b trial. Lancet 381, 1021-1028. doi: 10.1016/S0140-6736

Tamminga, C., Sedegah, M., Regis, D., Chuang, I., Epstein, J. E., Spring, M., et al. (2011). Adenovirus-5-vectored P. falciparum vaccine expressing CSP and AMA1. Part B: safety, immunogenicity and protective efficacy of the CSP component. PLoS ONE 6:e25868. doi: 10.1371/journal.pone.0025868

Tatsis, N., and Ertl, H. C. (2004). Adenoviruses as vaccine vectors. Mol. Ther. 10, 616-629. doi: 10.1016/j.ymthe.2004.07.013

Tatsis, N., Fitzgerald, J. C., Reyes-Sandoval, A., Harris-McCoy, K. C., Hensley, S. E., Zhou, D., et al. (2007a). Adenoviral vectors persist in vivo and maintain activated CD8+ T cells: implications for their use as vaccines. Blood 110 1916-1923. doi: 10.1182/blood-2007-02-062117

Tatsis, N., Lasaro, M. O., Lin, S. W., Haut, L. H., Xiang, Z. Q., Zhou, D., et al. (2009). Adenovirus vector-induced immune responses in nonhuman primates: responses to prime boost regimens. J. Immunol. 182, 6587-6599. doi: 10.4049/jimmunol.0900317

Tatsis, N., Lin, S. W., Harris-McCoy, K., Garber, D. A., Feinberg, M. B., and Ertl, H. C., (2007b). Multiple immunizations with adenovirus and MVA vectors improve CD8+ T cell functionality and mucosal homing. Virology 367, 156-167. doi: 10.1016/j.virol.2007.05.028

Tenbusch, M., Ignatius, R., Temchura, V., Nabi, G., Tippler, B., Stewart-Jones, G., et al. (2012). Risk of immunodeficiency virus infection may increase with vaccine-induced immune response. J. Virol. 86, 10533-10539. doi: 10.1128/JVI.00796-12

Thorner, A. R., and Barouch, D. H. (2007). HIV-1 vaccine development: progress and prospects. Curr. Infect. Dis. Rep. 9, 71-75. doi: 10.1007/s11908-007-0025-0 
Tregoning, J. S., Buffa, V., Oszmiana, A., Klein, K., Walters, A. A., and Shattock, R. J. (2013). A "prime-pull" vaccine strategy has a modest effect on local and systemic antibody responses to HIV gp140 in mice. PLoS ONE 8:e80559. doi: 10.1371/journal.pone.0080559

Vaine, M., Wang, S., Liu, Q., Arthos, J., Montefiori, D., Goepfert, P., et al. (2010). Profiles of human serum antibody responses elicited by three leading HIV vaccines focusing on the induction of Env-specific antibodies. PLoS ONE 5:e13916. doi: 10.1371/journal.pone.0013916

Valentin, A., von Gegerfelt, A., Rosati, M., Miteloudis, G., Alicea, C., Bergamaschi, C., et al. (2010). Repeated DNA therapeutic vaccination of chronically SIV-infected macaques provides additional virological benefit. Vaccine 28, 1962-1974. doi: 10.1016/j.vaccine.2009.10.099

van Gils, M. J., and Sanders, R. W. (2013). Broadly neutralizing antibodies against HIV-1: templates for a vaccine. Virology 435, 46-56. doi: 10.1016/j.virol.2012.10.004

Van Rompay, K. K., Abel, K., Earl, P., Kozlowski, P. A., Easlick, J., Moore, J. et al. (2010). Immunogenicity of viral vector, prime-boost SIV vaccine regimens in infant rhesus macaques: attenuated vesicular stomatitis virus (VSV) and modified vaccinia Ankara (MVA) recombinant SIV vaccines compared to live-attenuated SIV. Vaccine 28, 1481-1492. doi: 10.1016/j.vaccine.2009. 11.061

Van Rompay, K. K., Abel, K., Lawson, J. R., Singh, R. P., Schmidt, K. A., Evans, T., et al. (2005). Attenuated poxvirus-based simian immunodeficiency virus (SIV) vaccines given in infancy partially protect infant and juvenile macaques against repeated oral challenge with virulent SIV. J. Acquir. Immune Defic. Syndr. 38 124-134. doi: 10.1097/00126334-200502010-00002

Vasan, S., Hurley, A., Schlesinger, S. J., Hannaman, D., Gardiner, D. F., Dugin, D. P., et al. (2011). In vivo electroporation enhances the immunogenicity of an HIV-1 DNA vaccine candidate in healthy volunteers. PLOS ONE 6:e19252. doi: 10.1371/journal.pone.0019252

von Gegerfelt, A. S., Rosati, M., Alicea, C., Valentin, A., Roth, P., Bear, J., et al. (2007). Long-lasting decrease in viremia in macaques chronically infected with simian immunodeficiency virus SIVmac251 after therapeutic DNA immunization. J. Virol. 81, 1972-1979. doi: 10.1128/JVI.01990-06

Wallace, A., West, K., Rothman, A. L., Ennis, F. A., Lu, S., and Wang, S. (2013). Post-translational intracellular trafficking determines the type of immune response elicited by DNA vaccines expressing Gag antigen of Human Immunodeficiency Virus Type 1 (HIV-1). Hum. Vaccin. Immunother. 9, 2095-2102. doi: 10.4161/hv.26009

Wang, S., Farfan-Arribas, D. J., Shen, S., Chou, T. H., Hirsch, A., He, F., et al. (2006a). Relative contributions of codon usage, promoter efficiency and leade sequence to the antigen expression and immunogenicity of HIV-1 Env DNA vaccine. Vaccine 24, 4531-4540. doi: 10.1016/j.vaccine.2005.08.023

Wang, S., Kennedy, J. S., West, K., Montefiori, D. C., Coley, S., Lawrence, J., et al. (2008b). Cross-subtype antibody and cellular immune responses induced by a polyvalent DNA prime-protein boost HIV-1 vaccine in healthy human volunteers. Vaccine 26, 1098-1110. doi: 10.1016/j.vaccine.2007.12.024

Wang, S., Pal, R., Mascola, J. R., Chou, T. H., Mboudjeka, I., Shen, S., et al. (2006b). Polyvalent HIV-1 Env vaccine formulations delivered by the DNA priming plus protein boosting approach are effective in generating neutraliz ing antibodies against primary human immunodeficiency virus type 1 isolates from subtypes A, B, C, D and E. Virology 350, 34-47. doi: 10.1016/j.virol.2006. 02.032

Wang, S., Zhang, C., Zhang, L., Li, J., Huang, Z., and Lu, S., (2008a). The relative immunogenicity of DNA vaccines delivered by the intramuscular needle injection, electroporation and gene gun methods. Vaccine 26, 2100-2110. doi: 10.1016/j.vaccine.2008.02.033

Wang, S. W., Bertley, F. M., Kozlowski, P. A., Herrmann, L., Manson, K., Mazzara, G., et al. (2004). An SHIV DNA/MVA rectal vaccination in macaques provides systemic and mucosal virus-specific responses and protection against AIDS. AIDS Res. Hum. Retroviruses 20, 846-859. doi: 10.1089/0889222041725253

Wang, Y., Guo, Y., Wang, X., Huang, J., Shang, J., and Sun, S. (2011). Human serum amyloid $\mathrm{P}$ functions as a negative regulator of the innate and adaptive immune responses to DNA vaccines. J. Immunol. 186, 2860-2870. doi: 10.4049/jimmunol.1003641

Wang, Y., Guo, Y., Wang, X., Huang, J., Shang, J., and Sun, S. (2012). Serum amyloid P component facilitates DNA clearance and inhibits plasmid transfection: implications for human DNA vaccine. Gene Ther. 19, 70-77. doi: $10.1038 /$ gt.2011.67
Webster, D. P., Dunachie, S., Vuola, J. M., Berthoud, T., Keating, S., Laidlaw, S. M., et al. (2005). Enhanced T cell-mediated protection against malaria in human challenges by using the recombinant poxviruses FP9 and modified vaccinia virus Ankara. Proc. Natl. Acad. Sci. U.S.A. 102, 4836-4841. doi: 10.1073/pnas.0406381102

Whelan, K. T., Pathan, A. A., Sander, C. R., Fletcher, H. A., Poulton, I., Alder, N. C., et al. (2009). Safety and immunogenicity of boosting BCG vaccinated subjects with BCG: comparison with boosting with a new TB vaccine, MVA85A. PLoS ONE 4:e5934. doi: 10.1371/journal.pone.0005934

Widera, G., Austin, M., Rabussay, D., Goldbeck, C., Barnett, S. W., Chen, M., et al. (2000). Increased DNA vaccine delivery and immunogenicity by electroporation in vivo. J. Immunol. 164, 4635-4640. doi: 10.4049/jimmunol.164. 9.4635

Winstone, N., Wilson, A. J., Morrow, G., Boggiano, C., Chiuchiolo, M. J., Lopez, M., et al. (2011). Enhanced control of pathogenic Simian immunodeficiency virus SIVmac239 replication in macaques immunized with an interleukin-12 plasmid and a DNA prime-viral vector boost vaccine regimen. J. Virol. 85, 9578-9587. doi: 10.1128/JVI.05060-11

Xiang, Z., Gao, G., Reyes-Sandoval, A., Cohen, C. J., Li, Y., Bergelson, J. M., et al. (2002). Novel, chimpanzee serotype 68-based adenoviral vaccine carrier for induction of antibodies to a transgene product. J. Virol. 76, 2667-2675. doi: 10.1128/JVI.76.6.2667-2675.2002

Xiang, Z., Li, Y., Cun, A., Yang, W., Ellenberg, S., Switzer, W. M., et al. (2006). Chimpanzee adenovirus antibodies in humans, sub-Saharan Africa. Emerging Infect. Dis. 12, 1596-1599. doi: 10.3201/eid1210.060078

Xiang, Z. Q., Gao, G. P., Reyes-Sandoval, A., Li, Y., Wilson, J. M., and Ertl, H C. (2003). Oral vaccination of mice with adenoviral vectors is not impaired by preexisting immunity to the vaccine carrier. J. Virol. 77, 10780-10789. doi: 10.1128/JVI.77.20.10780-10789.2003

Xiang, Z. Q., Knowles, B. B., McCarrick, J. W., and Ertl, H. C. (1995). Immune effector mechanisms required for protection to rabies virus. Virology 214, 398-404. doi: 10.1006/viro.1995.0049

Xiang, Z. Q., Pasquini, S., and Ertl, H. C. (1999). Induction of genital immunity by DNA priming and intranasal booster immunization with a replication-defective adenoviral recombinant. J. Immunol. 162, 6716-6723.

Xiang, Z. Q., Yang, Y., Wilson, J. M., and Ertl, H. C. (1996). A replication-defective human adenovirus recombinant serves as a highly efficacious vaccine carrier. Virology 219, 220-227. doi: 10.1006/viro.1996.0239

Yan, J., Yoon, H., Kumar, S., Ramanathan, M. P., Corbitt, N., Kutzler, M., et al. (2007). Enhanced cellular immune responses elicited by an engineered HIV-1 subtype B consensus-based envelope DNA vaccine. Mol. Ther. 15, 411-421. doi: 10.1038/sj.mt.6300036

Yang, H., Dong, T., Turnbull, E., Ranasinghe, S., Ondondo, B., Goonetilleke, N., et al. (2007c). Broad TCR usage in functional HIV-1-specific CD8+ T cell expansions driven by vaccination during highly active antiretroviral therapy. J. Immunol. 179, 597-606. doi: 10.4049/jimmunol.179.1.597

Yang, T. C., Dayball, K., Wan, Y. H., and Bramson, J. (2003a). Detailed analysis of the CD8+ T-cell response following adenovirus vaccination. J. Virol. 77, 13407-13411. doi: 10.1128/JVI.77.24.13407-13411.2003

Yang, T. C., Millar, J. B., Grinshtein, N., Bassett, J., Finn, J., and Bramson, J. L., (2007a). T-cell immunity generated by recombinant adenovirus vaccines. Expert Rev. Vaccines 6, 347-356. doi: 10.1586/14760584.6.3.347

Yang, T. C., Millar, J., Groves, T., Grinshtein, N., Parsons, R., Takenaka, S., et al. (2006). The CD8+ T cell population elicited by recombinant adenovirus displays a novel partially exhausted phenotype associated with prolonged antigen presentation that nonetheless provides long-term immunity. J. Immunol. 176, 200-210. doi: 10.4049/jimmunol.176.1.200

Yang, T. C., Millar, J., Groves, T., Zhou, W., Grinshtein, N., Parsons, R., et al. (2007b). On the role of CD4+ T cells in the CD8+ T-cell response elicited by recombinant adenovirus vaccines. Mol. Ther. 15, 997-1006. doi: 10.1038/sj.mt.6300130

Yang, Z. Y., Wyatt, L. S., Kong, W. P., Moodie, Z., Moss, B., and Nabel, G. J., (2003b). Overcoming immunity to a viral vaccine by DNA priming before vector boosting. J. Virol. 77, 799-803. doi: 10.1128/JVI.77.1.799-803.2003

Yu, Q., Jones, B., Hu, N., Chang, H., Ahmad, S., Liu, J., et al. (2006). Comparative analysis of tropism between canarypox (ALVAC) and vaccinia viruses reveals a more restricted and preferential tropism of ALVAC for human cells of the monocytic lineage. Vaccine 24, 6376-6391. doi: 10.1016/j.vaccine.2006. 06.011 
Yuki, Y., and Kiyono, H. (2003). New generation of mucosal adjuvants for the induction of protective immunity. Rev. Med. Virol. 13, 293-310. doi: $10.1002 / \mathrm{rmv} .398$

Zhang, S., Huang, W., Zhou, X., Zhao, Q., Wang, Q., and Jia, B. (2013). Seroprevalence of neutralizing antibodies to human adenoviruses type- 5 and type-26 and chimpanzee adenovirus type-68 in healthy Chinese adults. J. Med. Virol. 85, 1077-1084. doi: 10.1002/jmv.23546

Zhang, X., Cassis-Ghavami, F., Eller, M., Currier, J., Slike, B. M., Chen, X., et al. (2007). Direct comparison of antigen production and induction of apoptosis by canarypox virus- and modified vaccinia virus ankara-human immunodeficiency virus vaccine vectors. J. Virol. 81, 7022-7033. doi: 10.1128/JVI.02654-06

Zhang, Y., Chirmule, N., Gao, G. P., Qian, R., Croyle, M., Joshi, B., et al. (2001). Acute cytokine response to systemic adenoviral vectors in mice is mediated by dendritic cells and macrophages. Mol. Ther. 697-707. doi: $10.1006 /$ mthe. 2001.0329
Conflict of Interest Statement: The author declares that the research was conducted in the absence of any commercial or financial relationships that could be construed as a potential conflict of interest.

Received: 30 June 2014; accepted: 03 August 2014; published online: 22 August 2014. Citation: Ondondo BO (2014) The influence of delivery vectors on HIV vaccine efficacy. Front. Microbiol. 5:439. doi: 10.3389/fmicb.2014.00439

This article was submitted to Microbial Immunology, a section of the journal Frontiers in Microbiology.

Copyright $(02014$ Ondondo. This is an open-access article distributed under the terms of the Creative Commons Attribution License (CC BY). The use, distribution or reproduction in other forums is permitted, provided the original author(s) or licensor are credited and that the original publication in this journal is cited, in accordance with accepted academic practice. No use, distribution or reproduction is permitted which does not comply with these terms. 